\title{
Symbols of Mystical Ecstasy and Divine Love in the Poetry of 'A'ishah al-Ba'uniyya and W.B. Yeats: \\ A Heideggerian Re-interpretation
}

\author{
Gehan M. Anwar Deeb* \\ gehan.anwar.lang@o6u.edu.eg
}

\begin{abstract}
:
Ecstasy, though, is an inexpressible and condensed experience through which the Ultimate can be revealed, the mystic poet finds expression in resorting to symbolism to reflect the uniqueness of his/her spiritual experience and to communicate the unsaying. Approaching the divine essence and expressing the euphoria of His presence in meditation, recollection and self-forgetfulness are often described as provoking ecstatic trance-like states of intoxication, dancing, flying, or even death. Within a broad interest in comparative mystical literature, this study traces the creative merit and the mystical layers of significance behind the writings of the Arab Sufi 'A'ishah al-Ba'uniyya and the Irish poet, W.B. Yeats. It follows a synthesis model, mainly Heidegger's existentialist view of ecstasy that envisages non-temporality presence, epiphany, transcendence and the experience of Being or Dasein, Jung's concept of individuation, and the Sufi theory of Ibn Arabi and Ibn alFarid. This paper examines the interpretation of 'Aishah's and Yeats' spiritual visions, though different in culture, religion and gender, in terms of a powerful and beautiful poetic endeavour. Their mystical poetry reveals a blend of Western and Eastern thoughts though it is dominated by a single Sufi touch. Their symbolism of love and ecstasy reveals the lovers' yearning to drink the undrinkable, and how "They are drunk on cups of love" to approach the Absolute. Since wine intoxication is forbidden in Islam, though Halal in the afterlife, it is used beyond even the sensual realm. This paper also investigates how spiritual dimensions, like transport, unveiling, illumination and beauty of the divine beloved, are exquisitely and metaphorically interconnected with physical love symbology--the wine, woman, roses, gyres, and shapes, in the process of elevating the erotic to the sanctity of the spiritual realm and integrating gender differences in the conscious quest for union with the Absolute.
\end{abstract}

Keywords: Symbolic poetry; al-Ba'uniyyah and Yeats; Heidegger's the Ultimate Truth; mystical ecstasy and divine love; Jung's individuation

${ }^{*}$ Associate Professor of English Literature, The Department of English, October 6 University.

(Symbols of Mystical Ecstasy and Divine Love...) Dr. Gehan Deeb 


\section{Introduction:}

The great mystics are creative and innovative, as they left a continuum of writings replete with love and ecstasy in Arab and English literature through the ages, and in various cultures and traditions. Examining a single image from several culturally different perspectives attempts to describe an "excessive love", joy and ecstasy which are inexplicable, and, nevertheless, of undeniable importance in mystical literature, more importantly in mystical poetry.

Since ecstasy is a condensed experience to reach the Ultimate, it is hardly expressed in prose and poetry. So, the mystic poet finds expression in employing esoteric and love symbols and imagery through which man is connected to 'the Divine and His higher Self,' and related practices such as 'meditative thought,' remembrance or recollection, dancing, intoxication, and self-forgetfulness. My interest, to be concise, is to explore women's mysticism in Islam (Sufism) and men's mysticism in Christianity and other traditions, within a broad interest in comparative literature considering the mystical poetic career of two outstanding writers, i.e., the 16th-century Arabic Sufi writer, 'A'ishah al-Ba'uniyya, and the 20th-century Irish writer, William Butler Yeats. This study follows a synthesis model, mainly Martin Heidegger's existentialist view of ecstasy, Jung's concept of individuation, and the Sufi theory of Arabic Sufi masters, such as Ibn Arabi, Ibn al-Farid, and al-Ghazali. It attempts to describe the mystic's transcendent experience and the mystical themes that envisage non-temporality presence, epiphany, and the experience of Being or Dasein, to which Heidegger seeks and are similar to the experience of the Absolute toward which both al-Ba'uniyya and Yeats seek.

This analytical study tries to contribute to understanding the mystical meaning behind the symbols used by both creative writers. The mystic and the poet share emotions and imagination at a higher level, yet different in function. Their visions, images, and symbols are their tools through which the feelings of ecstasy or rapture may be objectivized, and the mystical experience conveyed.

\section{1-1. A Heideggerian and Mystical Approach:}

Though Heidegger is a philosopher, he also has a mystical side, as evinced in his ideas, relying on Jeff Guilford's paper "Was Heidegger a mystic?" in which he explores the analogies between Heidegger's philosophy and the mystics'. "Like Heidegger, mystics reject metaphysical thought as an inadequate means by which the Absolute may be pursued," and suggest that "the Ultimate may be recognized and approached" (87). Guilford concludes

(Symbols of Mystical Ecstasy and Divine Love...) Dr. Gehan Deeb 
that "Heidegger's philosophy is in fact mystical, and that it is reasonable to think that the experience of Being to which Heidegger seeks to lead us, is essentially the same as the experience of the Absolute toward which the mystics of all cultures have persistently striven" (Ibid).

In his $\mathrm{PhD}$ philosophy dissertation on a comparative study of the great Sufi Rumi and Meister Eckhart (1971), Manoochehr Ashtiani interestingly argues that "Heidegger is a mystic, not a philosopher." In a long interview in Tehran Times (2017), this professor of philosophy and sociology pointed out that there are similarities between Western philosophers and Muslim mystics (Sufis).

[T] he comparisons are not without merit. I published it under the title of Historical Sociology. In this book, I showed that Mawlana [Rumi], Eckhart and Heidegger's ideas are not philosophical but mystical. Gadamer read my works and told me that I was right, he told me that "for the last thirty years, I've been saying that my dear teacher, Heidegger, is a mystic, but no one believes me. You are the first one that has written this down." It is surprising that Mr Ayatollahi, Davari Ardakani and Dinani also believed this and they told me once that Heidegger's being a mystic is the reason that they agree with his ideas. I told them that because I believe that Heidegger is a mystic, I am rejecting and criticizing him because Heidegger is deviating from the rational German philosophy. (Rezaei, www.tehrantimes.com)

\section{1-2. The language of Unsaying: Ecstasy beyond Temporal and Spatial Limits:}

One of the principles of mysticism, and therefore of the spiritual states of Sufism, is termed ecstasy. The term implies many meanings including bliss, rapture, transport, and rhapsody. In his book Being and Time (1927), Martin Heidegger's concept of ecstasy is explored relating the term to Ancient Greek ekstasis or Latin ecstasis, which etymologically means "to be or stand outside oneself, a removal to elsewhere", "a stand at a certain place"; i.e., removing oneself from the realities of earthly existence and into a mythical or mystical level of existence. To become 'ecstatic' means to stand out of the visible and into its 'other side.' Heidegger has used the term 'ecstatic' to explain the way Dasein "stands out" within the various moments of the temporality of care, in the context of the "existential analysis" of our "being-in-the-world." His view on the 'three ecstasies of temporality,' namely past, present and future, suggests that one can transcend himself/herself being "thrown" out of a past (our thrownness/disclosedness) and "projecting" itself toward a possible future (our projection/ understanding) by way of the present (Being and Time, 203-04). These

(Symbols of Mystical Ecstasy and Divine Love...) Dr. Gehan Deeb 
'ecstasies' of time are "the three ways in which the irreducible dynamism of existence opens us to what is outside ourselves, to that which is other" (Abram 125). In the mystical sense, the poet's visions of the past are recreated within the other two ecstasies of poetic time, the present and future in what is called a "personal lost circle of perfection" (Ullah 84).

Heidegger's view on poetry, language, vision, truth, illumination, soul, the Ultimate, and transcendence (great factors in mysticism) are defined in terms of ecstasy and beauty to be felt and seen. The multicultural phenomenon of ecstasy is laden with symbols that communicate meanings and ideas in every culture. Ecstasy, though, is inexplicable and condensed experience, the seeker finds expression in meditation, mental exercise, intoxication, dancing, flying, and self-forgetfulness. The varied aspects of semiotics as analytical tools are useful to understand the mystical ecstasy and divine love in W.B. Yeats and 'A'ishah al-Ba'uniyya. Semiologists built on Saussure's foundation of three components, the signifier, the signified, and the sign. Some signs may carry a cultural meaning, becoming a myth, as described in Roland Barthes' version of semiotics, or archetypes that do not represent a certain sign as described by Carl Jung.

\section{1-3. Language and Individuation:}

Mystical symbols are three types: intellectual symbols (such as that connote the connection between the mystic and God); sensual symbols (direct symbols derived from the phenomenal world with artistic depth and multiple connotations, like a tree, a rose, a woman, or a bird); and figurative symbols (as an indirect expression for various abstract and esoteric meanings that transforms images to symbols). In his book Analytical Psychology, Jung proposes that symbols cope with a textual language that consists of words, signs, expressions, gestures, and visual imagery. They are shapes that "have been used to connect man to the divine and his higher self" (Chanda-Vaz 45) and to infer meanings. For Jung, the stages of a passage or a journey towards unity belong to a myth or an inborn archetype; they are human innate symbols originating from the collective unconscious that can be construed or reinterpreted upon assumptions. In Memories, Dreams and Reflections, Jung appears to envisage a literal belief in various concepts which he treats as figurative. For him, 'primordial' images and symbols are preexistent in the unconscious, motifs in myths, visions, and dreams, and can give rise to a conscious experience.

Only after I had familiarized myself with alchemy did I realize that the unconscious is a process, and that the psyche is transformed or developed by the relationship of the ego to the contents of the unconscious. In individual cases that transformation can be read from

(Symbols of Mystical Ecstasy and Divine Love...) Dr. Gehan Deeb 
dreams and fantasies. In collective life it has left its deposit principally in the various religious systems and their changing symbols. Through the study of these collective transformation processes and through understanding of alchemical symbolism I arrived at the central concept of my psychology: the process of individuation. (Jung 1963/1989, 209).

Accordingly, individuation is defined by Jung as a wholeness that is formulated from the fusion or union of those elements that are usually tugged in opposite directions, "it is usually an unfathomable mixture of conscious and unconscious factors, and therefore a symbol, a coin split into two halves which fit together precisely" (Ibid 335).

In an impressive article "Individuation and The Self" (2020), Martin Schmidt actually points out that individuation, as regarded by Jung, is "the process of self-realisation, the discovery and experience of meaning and purpose in life, the means by which one finds oneself and becomes who one really is. It depends upon the interplay and synthesis of opposites, e.g., conscious and unconscious, personal and collective, psyche and soma, divine and human, life and death." (3) Thus, individuation suggests the wholeness of self-realization and integration, and "the possibility for rarefied experiences and transformation of self which otherwise may not happen" (Ibid 1).

Both Yeats and 'A'ishah attempt to present and communicate complicated spiritual experiences and situations while adhering to the use of a specific artistic language. "It is rare enough to find personal documents that provide detailed descriptions of feelings (as opposed to just actions and thoughts)" (Nixon 8). Furthermore, according to Heidegger, anxiety represents "a phenomenon that occurs beyond the realm of language" (Guilford fn 1,88). Language and its structures here frame the unique mystical experience constituting a world different from other worlds of artists (non-mystical poets) who depend within their art on creative imagination and poetic image in the first degree. Additionally, "while all mystics affirm that the Ultimate is absolutely ineffable", Heidegger's concern is "to restructure language so that it can speak the truth of being, which is simply a task that no mystic has ever thought to take upon himself." (Guilford, fn. 7, 93).

\section{Sufi Symbolism: Symbols of Love 'mahabbah' as a Source of Ecstasy:}

The subject of lyrical poetry has remained the same for centuries. Love has always been the favourite: love between man and woman, or a girl and a boy (Rees 77). Courtly love or romantic devotion usually played a part in this context with relevance to other kinds of love that have also inspired the

(Symbols of Mystical Ecstasy and Divine Love...) Dr. Gehan Deeb 
mystic poet: The love between God and man, for instance, or man's love for the beauty of nature (Ibid). It is in these descriptions of love that 'A'ishah and Yeats sought to interpret and explain their mystic visions. They have excelled in harmoniously blending symbolic and aesthetic dimensions in a very spiritual context. Using the symbols and imagery of the romantic poets to ground the move to the love of God, the lovers, not always conscious of communicating that secret state of consciousness, woo the divine beloved as passionately as the famous human love stories. In Sufi love poetry, love 'mahabbah' is a metaphorical embodiment of God and the Prophet Muhammad is a desired and gendered poetic beloved (Ullah 132).

Furthermore, Sufi literature describes, in an implicit and highly metaphorical language, the experience of ecstasy and related practices, such as meditation, remembrance or recollection. However, ecstasy is not an aim, it is a mere means to achieve intimacy and union with God. Sufis believe that staying so long in exuberant ecstasy may create a veil in their way to Allah; hence thwarting the process of reaching their goal. At this point, it must be noted that a common characteristic of Sufi literature is the beauty of their symbolic language in their mystical texts. Every symbol in their works functions as a specific meaning - associated with allegory, metaphors, and antithesis - to describe their mystical journey of individuation to the Absolute. In what follows I shall mention some of these symbols and the meanings they denote within the Sufi framework. Significant terms are widely used; namely, the intoxication symbols of the wine and its relatedness to other symbols such as the bar, the tavern, the cupbearer or the beloved. Additionally, the heart of the seeker signifies God's house; the veil represents hindrance of God's union; a tree symbolizes God's grace; a breeze is a symbol for a new awakening to the real nature of life.

\section{2-1. 'A'ishah al-Ba'uniyya and the Wine Cup of Love:}

A'ishah bint Yūsuf ibn Ahmad al- Ba'uniyya (c.1456-1517) (referred hereinafter by 'A'ishah) was an outstanding Arab Muslim, mystic and scholar, who lived in Syria and Egypt. After memorizing the whole Quran at 8, like her father and uncle, she studied 'poetry, hadith and jurisprudence.' 'A'ishah was prolific; she composed over twenty works, Arabic poetry and prose, likely more than any other Arab woman prior to the twentieth century. She "was highly regarded as a pious woman and Sufi master" (Homerin, 2003, 216). "Her great uncle Isma'il had been a Sufi ascetic; her uncle Muhammad composed a devotional poem of over a thousand verses on the prophet Muhammad" (Ibid 213).

As a creative calligrapher, 'A'ishah wrote most of her works in her handwriting. Though many of her religious writings, Sufi poems in particular,

(Symbols of Mystical Ecstasy and Divine Love...) Dr. Gehan Deeb 
are lost today, several still exist in manuscripts flourished abundantly by later researchers and admirers, such as her autobiographical collection Fayd alFadl waJam' al-Shaml: The Emanations of Grace and the Gathering Union. Consisting of nearly 375 odes, this poetic collection (Dīwān) recounts her "remarkable story of devotion [to God and His prophet Muhammad] and mystical illumination," as well as it extensively expresses her "love and longing on the mystical quest for union," in the wider context of latemedieval Islamic spirituality (nomindisland.blogspot).

'A'ishah was skillful in employing multiple poetic styles, forms, purposes, and verbal and rhetorical images, associated with Arabic rhymes and meters. At the outset of most of the poems in Emanations of Grace, she describes the union of her physical and mystical states in life, such as "rapture was intense", and explains in notes the meanings of the Sufi terms, practices and quotations from Quran and Hadith, as well as interpretations of earlier classical Sufi works. As a Qadiri Sufi, and with regard to the classical Arabic convention in composing the Qasidah, 'A'ishah uses the poetics of a 'cluster' of images and descriptions in her collection associated with the Prophet Muhammad as a poetic beloved, a troubling matter in the Medieval Islamic context.

'A'ishah's poetry and rhetoric spring from her true Sufi individuation of the ecstatic experience and mystical love that necessitates another figurative language of symbolic and esoteric expressions (Ullah 151-3). She intentionally fuses the concepts of esotericism, beatitude, and the ultimate truth as pictorial indications of ecstasy and joy in terms of the imagery of intoxication and cups of love, highly poetic lines, visionary scenes, transcendental symbols, and structure. Seizing the aesthetic moment, or the instant of total assimilation, during which the poet functions all his artistic abilities to realize it, Sufis too express the euphoria of the precise correspondence between spiritual knowledge and physical love with other pictorial representations and sensual connotations of pleasure. 'A'ishah's poetry is distinguished by its originality, weaving and eloquence. What is artistically interesting is how the uniqueness of her poetic mystical experience in resorting to the symbolic wine, and therefore the manifestations of its language, may formulate a more different reality than men's poetry in this context. Her 'exceptionalism' or individuation is additionally visible in her person "as an intellectual and writerly figure" who "represents a radical break from male-dominated spaces" (Ibid 166). 'A'ishah wrote in ecstasy: ${ }^{1}$

${ }^{1}$ In analyzing 'A'ishah's selected poems or books, I will rely largely on the translations of Th. Emil Homerin, a professor of religion at the University of Rochester.

(Symbols of Mystical Ecstasy and Divine Love...) Dr. Gehan Deeb 

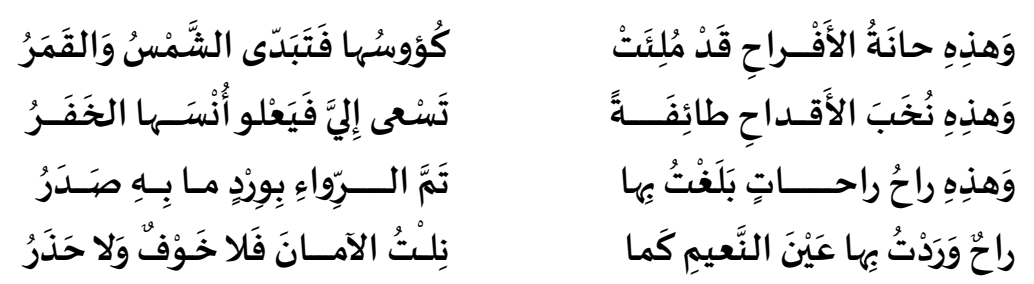

This is the tavern of joy where the glasses are full, aglow like the sun and the moon.

These choice cups are a portion of what comes to me as their quiet intimacy takes hold.

This is the wine of leisure, and I received from it perfect fulfillment from an endless source,

A wine taking me to the fountain of bliss, as I attained peace without anxiety or fear.

(Translation from Homerin, Emanations of Grace, Fons Vitae, 2011; Al- Ba'uniyya, Dīwān Fayḍ al-Faḍl, Arabic 378)

In a study on the poetry of 'A'ishah al-Ba'uniyya, Hassan Rababe'ah from Jordan attempts to uncover the features of the Sufi state of drunkenness or of being intoxicated in Divinity. Although wine is one of the rewards for the believers and the righteous in the afterlife, the mystic poet nevertheless presents it to us within its worldly framework and related scenes of the bar, the tavern, the cupbearer, drinking, singing and music. 'A'ishah therefore tries to develop such a relatedness to reach the climax of the state of drunkenness and ecstasy in God's love. The winery context is then divided into three stages: taste, drinking and then being quenched (Translation is mine; Rababe'ah 256). Taste happens to the tastier when beauty is manifested to him, and he gets something from it 'I received from it' - a general condition that formulates the start of the act. Drinking is a continuous condition in which beauty is manifested for an hour or two and that takes the mystic into an unknown time and place. Being Quenched means continuous drinking until the joints and veins become filled with the lights of the Divine Self, i.e., the 'perfect fulfillment from an endless source.' It is the end of the mystic's path that leads him to the truth of the fullness of the love of God and the eternal proximity to the Holy Self, 'the fountain of bliss' and 'peace'.

Most of 'A'ishah's poetry is rich in imagery; she even reemployed symbols from ordinary familiar life. In another book, Al-Muntakhab fì Ușūl al-Rutab fi 'Ilm al-Tașawwuf, translated as The Principles of Sufism, she wrote:

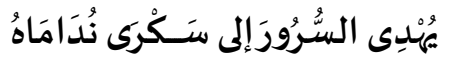
يا حَبَّذَا هَا كُؤوسُسًا أَنْشَأَتْ طَرَبًا

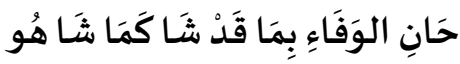

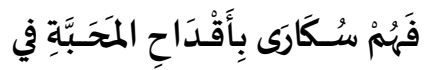

(Symbols of Mystical Ecstasy and Divine Love...) Dr. Gehan Deeb 


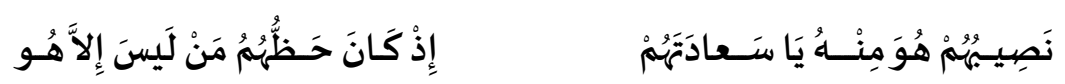

How wondrous are cups giving rise to pleasure

bringing joy to His companions' intoxication.

They are drunk on cups of love

in the tavern of realization as He pleases.

$\mathrm{O}$ masters, their portion is from Him,

for their share is no one save Him!

(Translation from Homerin. The Principles of Sufism, 92; al-

Ba'uniyya, Al-Muntakhab, Arabic 70)

Here, the passage emphasizes her mastery of language structure; relational creativity is thus reflected in the reliance on an intense poetic lexicon such as 'wondrous,' 'pleasure,' 'joy', 'intoxication', and 'pleases' indicating a state of exuberant mystical ecstasy, manifested in the direct connection between the states of intoxication and drinking from the 'cups of love.' Truly, this is evident in the following form as well:

$$
\begin{aligned}
& \text { ما داركأسك على قلبي بمشروبك في حال قربي }
\end{aligned}
$$

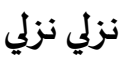

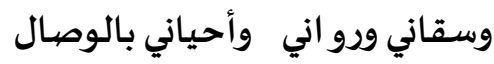

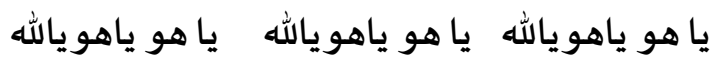

$$
\begin{aligned}
& \text { يا هو ياهو يالله }
\end{aligned}
$$

As long as Your cup comes round to my heart

with Your wine in the tavern of nearness,

my drink, my drink,

given to me to drink, quenching me, and reviving me in union!

Yā Hū, yā Hū, yā Allāhu, yā Hū, yā Hū, yā Allāhu, yā Hū, yā Hū, yā

Allāhu, yā Hū, yā Allāhu!

(Translation from Homerin, "Recalling You, My Lord" 146; Arabic 153-4)

'A'ishah alludes to the symbol of the winery to uncover some meanings related to her mystical world, and in this, she has shared the poetic convention of the Arabs and predecessors in describing the wine on the one hand, and from the heritage of the Sufi figures - 'Umar ibn al-Fāriḍ (d. 632/1235), Muhỵī al-Dīn ibn 'Arabi (d. 638/1240) and Muhammad al- Būṣīīi (12111294) - in their khamriyyāt, on the other hand, to express divine love, their goal and end. In composing bad̄̄ 'iyyāt in form and content, 'A'ishah was inspired by Ibn al-Fāriḍ's famous Khamriyyah (the Sultan of Lovers) or "The

(Symbols of Mystical Ecstasy and Divine Love...) Dr. Gehan Deeb 
Wine Ode" and his long mystical poem the Al-Tã'iyyah al-Kubrá ("The Ode in T-Major") and she composed The Ode in "T" or Ta' 'iyyah of 252 verses modelling on it. There is no denying the fact that the quest for the state of intoxication indicates the desire to communicate the experience and convey the feeling of the poet as an individual without identifying the details of temporality and spatiality. 'A'ishah in her Tà'iyyah recalls Ibn al-Fāriḍ who wrote,

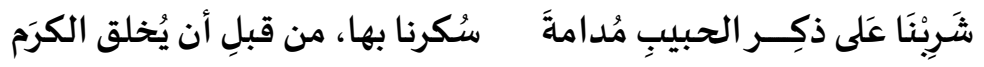

In memory of the beloved we drank a wine;

We were drunk with it before the creation of the vine.

(Translation from Homerin, 'Umar Ibn Al-Fāriḍ: Sufi Verse, Saintly

$$
\text { Life, 47) }
$$

The notion of limitless temporality, pre-eternity in time and space, is commonly used by the Sufi writers in connection with the winery context. The classical image of locating the poet-lover and the cupbearer in a tavern offering wine, shelter, and sociability to the poet is especially significant to suit the mystical purpose and the metrical composition. 'A'ishah "locates the action of being quenched by the cupbearer of love in pre-eternity before bodily existence" (Ullah 168) in the material world. She writes,

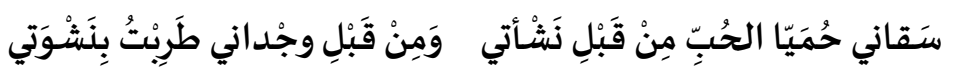

He quenched me with love's heady wine before my birth,

And I delighted in my drink prior to my being.

(Translation from Homerin, Emanations of Grace, 2011, 97; Arabic 237.)

Accordingly, the symbolic tavern offers the purest wine of pre-eternal life. 'A'ishah, like her predecessor Ibn al-Fārid, articulates "the lover has drunk of the wine before her birth as in "before the creation of the vine." Similarly, she plays with the conceit of remembering pre-existence or pre-eternity" (Ullah 169). Thus, the stage of being quenched was accomplished in preexistence (an unknown time), and the wine puts the people of drinking "love's heady wine" (Homiyya al-hob) in the maze of the unknown (an unknown place) and from the cup, the soul emanates (an unknown body) (Translation is mine; Rababe'ah 256). 'A'ishah's poetry also depicts a physical world and a "timelessness world" similar to the poetry of Ibn al-Fārid, "who refers to the cosmic, the symbolic, and the spiritual in the prelude to his khamriyyāt" (Ullah 74). The opening verse of her "T" Tã'iyyah echoes his Major Tã 'iyyah by way of the meter, rhyme, imagery and symbolism. His prelude begins,

(Symbols of Mystical Ecstasy and Divine Love...) Dr. Gehan Deeb 


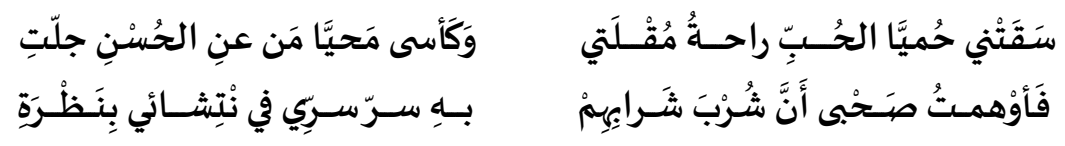

The palm of my eye handed me love's heady wine to drink, And my glass was a face of one revealing loveliness.

Drunk by my glance I caused my companions to suppose That drinking their wine had brought my heartjoy.

(Translation from Homerin, 'Umar Ibn al-Fārid: Sufi Verse, Saintly Life, 75.)

\section{2-2. Conceptual Metaphor of the Divine Beloved}

'A'ishah, as previously explained, employs the wine symbol of mystical love related to the three conditions of wine. According to Dakake:

The image of the Sufi seeker consumed by desire for the Divine Essence-sometimes described as a mysteriously beautiful and "veiled" Beloved - is given a good deal of poetic and rhetorical play in the works of Sufi literature. This image derives much of its symbolic force from the assumption that the Sufi seeker is himself the male lover, seeking the sublime Divine Essence metaphorically conceived of in feminine terms. (72)

Ibn al-Fārid is extremely famous for employing the woman symbol in his poetry as an unrivalled beloved, elevating her to a rare manifestation of the divine complete beauty in the universe. In his ode "the Sufi seeker is often represented as a male lover in relation to God as the symbolically and "feminine" Beloved." On the other hand, conversely, in 'A'ishah's Tà'iyyah, the seeker is gendered feminine who "developed [her] own image of the Divine Beloved as the symbolically masculine object of [her] female desire. ..., reflecting a distinctly and traditionally female experience of loving and spiritual longing" (Dakake 72). Having made this distinction, we may further observe that 'A'ishah "consistently refers to the self with the pronouns "I" or "me" or "my" and to the desired beloved with the pronoun "he" or "him" or "his" (Ullah 170). After attaining the "wine cup of love", 'A'ishah writes,

$$
\text { وَماذا عَسى عَنَّى يُقالُ سِوى فَنى وُجودًا، أنا الفاني بِباقي الهُوِيّة }
$$

What could be said of me save that the passing existence of "I"

Passed away in the everlasting existence of "Him"

(Translation from Homerin, Emanations of Grace, 109; Arabic 243)

The "conceptions of divine love" are commonly acknowledged as often "expressed with spiritual confidence and warm devotion" (Dakake 79). However, 'A'ishah sometimes departs from her predecessors and draws from

(Symbols of Mystical Ecstasy and Divine Love...) Dr. Gehan Deeb 
her own work. She boldly plays the role of the mu'adhkin, "the one who calls to prayer - the most recognizable public voice of the Muslim community within a city or village" (Ullah 172).

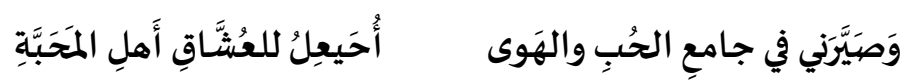

In the mosque of love and passion, he made me call to prayer Impassioned lovers, the worthy ones of love.

(Translation from Homerin, Emanations of Grace, 97; alBa'uniyya, Dīwān Fayḍ al-Faḍl, Arabic 238.)

In fact, 'A'ishah's individuation does not alienate her from her community; rather, it brings her community within the wholeness of her self. She describes the Jami', or the mosque, as a symbolic public space where lovers can meet. She makes her own way of thinking unlike Ibn al-Farid's tavern of hidden lovers where the 'brave young men' are used to hide his lover, believing that the union cannot be achieved unless the lover is kept alone and at a non-public space. He writes,

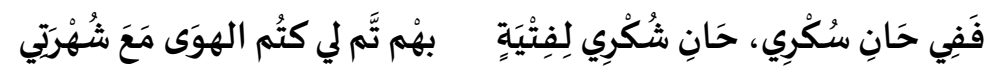

So in the tavern of my drunkenness was the time of my thanks to brave young men,

For despite my infamy, I completely hid my love with them.

(Translation from Homerin, 'Umar Ibn Al-Fārid: Sufi Verse, Saintly Life, 75.)

\section{Ecstasy of the Quest of the Truth of Being:}

Ecstasy is an experience during which the very vision of time, space or the self changes or disappears. Jeff Guilford demonstrates the strong analogies between the methods of Heidegger and those of the mystics. The analogy works and reinforces Heidegger's proposition that "an experience of Being may be attained to the ways that mystics from many cultures have gone about bringing themselves to an experience of the transcendent" (86). In Letter on Humanism, Heidegger believes that "Being is the transcendens pure and simple" (256). On defining Da-sein Heidegger says that it brings man "back to his essence," namely, "the ecstatic inherence in the Truth of Being. The ecstatic essence of the human being consists in ek-sistence"(248).

In his Discourse on Thinking, Heidegger seeks, as the mystics do, to experience the Ultimate, through practising "meditative thought" that "contemplates the meaning which reigns in everything that is" (46); (Guilford 86-93). Accordingly, there are practices that lead to the mystical experience that once the seeker attains, "he or she cannot escape this overwhelming

(Symbols of Mystical Ecstasy and Divine Love...) Dr. Gehan Deeb 
feeling. He or she has to give in to this transcendental sensation" (Tülüce 12). However, contemplation is not enough to attain the state of transcendence, a spiritual journey is required, as Algis Uždavinys contends:

The spiritual ascent is not a theoretical journey undertaken by reason, but (like the Sufi mi'raj) it is a movement in consciousness, active imagination, and spirit, which transforms one's being and brings an inner unification and union (henosis) with the divine. The supreme goal of human life is to be united to the Good who is above all things.(31)

\section{3-1. Ecstatic Trances for the Ultimate Truth and Union}

The poet passes through three main stages in the composition of a great poem: poetic inspiration (spirit or vision), creative beauty (delight), and music meaning. Likewise, the mystic passes through four stages of the spiritual journey: Path, Observance, Truth and Union. The last stage, according to al-Ghazzali in his Confessions, could only be reached by "transport, ecstasy, and the symbolist transformations of the morality being" (Qtd in Nixon 29). The visionary poetry can be adaptable to yield allegorical themes as a manipulation of the language of symbols. The mystic poet allegorically deals with the human body, male and female, and its relation to God. Symbols are used "as an element to help further his spiritual cause", (Chanda-Vaz 5) and as a tool used as part of the mystic's spiritual journey. This journey is called Taoism/Daoism or 'The Way' in the Eastern and FarEastern spirituality traditions. It is meant to be an upward way of the soul. When the mystic's soul or self is eventually united with God in an ecstasy of total surrender, the physical and the spiritual are united. "C W Leadbeater (1927) suggests that a 'Chakra refers to the ancient Hindu concept of seven vortices of energy located on the spine from the tailbone to the crown of the head. These centers define the physical and spiritual contact points in the human body. In yoga they are bridges to higher consciousness symbolizing the journey from the material world to the divine.'" (Ibid 21)

Furthermore, the Muslim mystic/Sufi experiences an ecstatic yearning for God, Prophet Muhammad, and sacred places, like al-Madinah (the Illuminated City), as a rite of passage. The rite of passage is a vital element before praising the beloved subject. "In mystical literature, Islamic and otherwise, the outward physical journey is a standard metaphor and expression for the inward spiritual journey; but for most Sufi women, the spiritual journey was both symbolically and physically an inward one" (Dakake 82). 'A'ishah alludes to mystical allegories of the Islamic pilgrimage that she made with her family as a young woman, during which she had a vision of the prophet Muhammad (PBUH) that would change her life completely forever. Consequently, at the end of her long ode in " $T$ ", 'A'ishah

(Symbols of Mystical Ecstasy and Divine Love...) Dr. Gehan Deeb 
leaves Ibn al-Farid's poems aside as she turns to praise the prophet Muhammad and seek his intercession.

\section{3-2. Recollection (dhikr) as a Sign of Love and the Way to Transcendence and Transformation:}

In order to experience spiritual transcendence, according to 'A'ishah, the seeker must practise $d h i k r$, recollection or remembrance. In her compendium, Al-Muntakhab fì Ușūl al-Rutab fì 'Ilm al-Tașawwuf, or The Principles of Sufism,

' $\bar{A}$ 'ishah likens Sufism to a tree of many branches, yet having four essential roots or principles: tawbah (repentance), ikhlās (sincerity), dhikr (recollection), and mahabbah (love)... [A] higher, selfless, love demands a spiritual purification and transformation through $d h i k r$, or the recollection of God, followed by His grace. ' $\overline{\mathrm{A}}$ ' ishah begins her discussion of this third principle of dhikr by quoting God's promise in the Quran (2:152): «fa-dhkurünī, adhkurkum»; «So remember Me, and I will remember you.» (Homerin, 2013, 138).

Discussing recollection and how it leads to a state of mystical transformation, 'A'ishah cites a Prophetic tradition that helps realize the moment of spiritual transcendence and mystical union with God through recollecting the phrase: "lā ilāha illā llāhu", "There is no deity but God" and considers it among the signs of love. This is the final stage, where a true lover is effaced completely in the divine Beloved, at that moment God "become his sense of hearing with which he hears, and his sense of sight with which he sees, and his hand with which he grips, and his leg with which he walks" (Sahih al-Bukhari, Hadith 6502). Thus, the Truth, the Absolute, or the Ultimate is revealed at that time by Himself. The mystic's quest for the Divine love, and his/her nostalgia for the time and place related to Him, are shown in an excellent bit of imagery which develops 'A'ishah's experience along the following expressive passage:

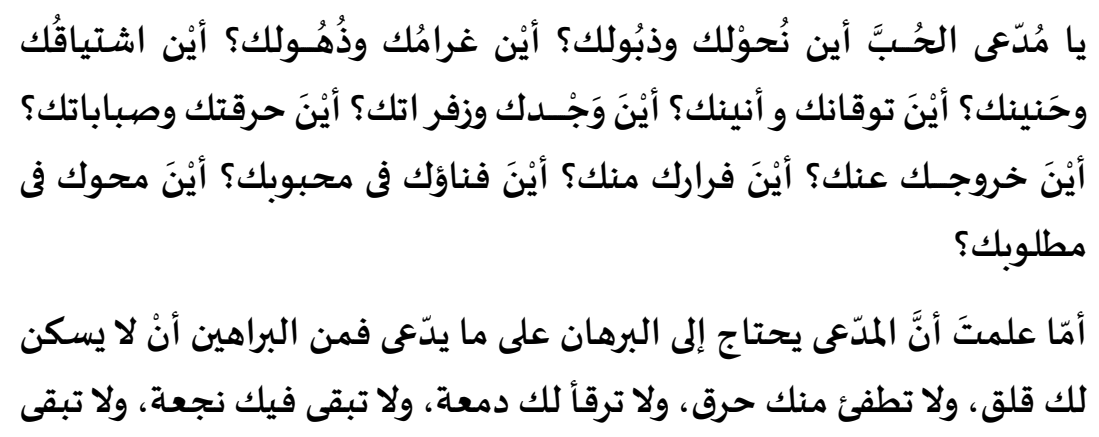

(Symbols of Mystical Ecstasy and Divine Love...) Dr. Gehan Deeb 


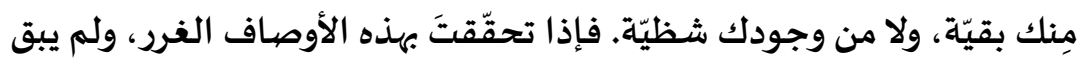

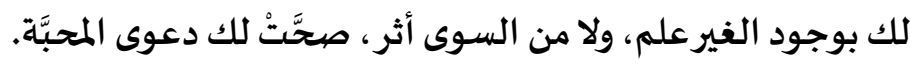

You, love's pretender, where are your wasting away and your anguish? Where are your burning passion and your dismay? Where are your longing and your yearning? Where are your craving and your groaning? Where are your grief and your sighing? Where are your agony and your ardent love? Where is your taking leave of yourself? Where is your fleeing from yourself? Where is your annihilation in your beloved? Where is your effacement in the one you seek? Don't you know that one who claims to love requires clear proof for his claim? Clear proofs include always being restless with anxiety, unceasing anguish, flowing tears, and loss of appetite. No remnant remains of you, not even a splinter of your existence. If you prove to have these outstanding traits without any sign or trace of love for another, then your claim to love is true.

(Translation from Homerin, The Principles of Sufism, 2016, 91; al-Ba'uniyya, al-Muntakhab, Arabic 69)

This passage indicates that her selection of succinct questions and phrases in her language is a fundamental point to her quest for God's love. Homerin describes the type of 'A'ishah's Emanations of Grace as 'a meditative verse,' or in his terms the 'poetry of recollection' that reflects 'A'ishah's endeavours to describe her love for God. "In such verse, through a process of memory, reflection, and understanding, the poet draws near to God, and in her imagination experiences His love and grace" (Homerin, 2011, 136). The poems in this collection have various religious and mystical themes but are mostly focused on the love of God and His prophet Muhammad, the importance of recollection, spiritual intoxication, and mystical union. She writes:

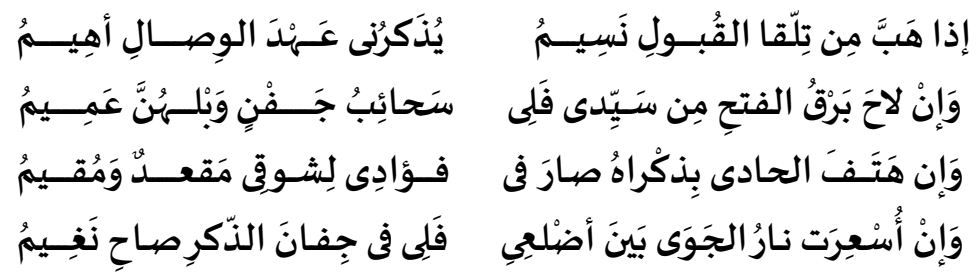

When a breeze of acceptance wafts in, a deep love reminds me of union's covenant,

(Symbols of Mystical Ecstasy and Divine Love...) Dr. Gehan Deeb 
And when a flash of inspiration appears from my Lord, my eyes cloud up and pour.

When the leader calls out His name as the caravan departs, desire wants my heart to stay,

And when passion's fire is kindled in my ribs, then, my friend, I take a drink from recollection's cups.

(Translation from Homerin, "Recalling You, My Lord" 135; Arabic 148.)

'A'ishah in this passage uses significant and carefully selected words in a symbolic form, apparently 'flash,' 'desire,' 'passion' and 'fire.' The emblematic values of these words, for instance, primarily point to her deepest feelings and expressions of love. Her final decision is to be intoxicated by the pure wine contained in the cups of recollection: 'calls out His name' and 'recollection's cups'. 'A'ishah proceeds,

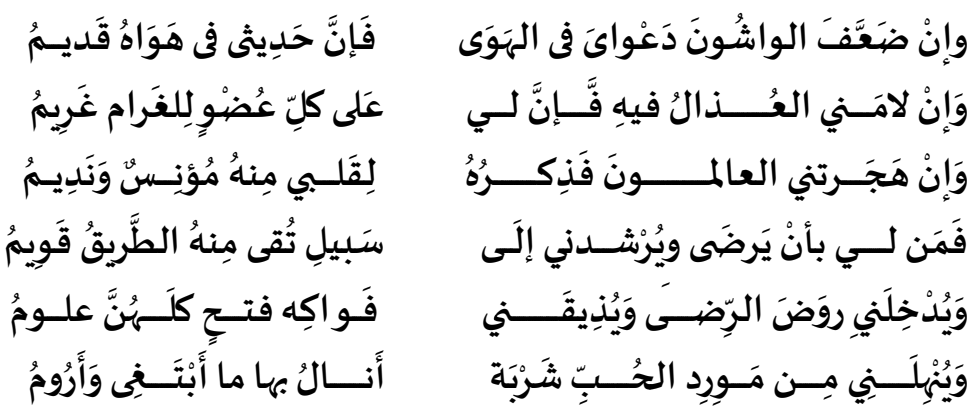

If critics belittle my claims to love, well, ancient is my tale of love for Him,

And when others slander me because of Him, my every limb opposes them with passion.

If all the world abandons me, recollection of him remains my heart's close companion and friend.

When the One I love is pleased, He guides me to the path of righteousness, the straight path,

And $\mathrm{He}$ brings me to the pastures of acceptance and gives me a taste of inspiration's fruitful knowledge.

He gives me a drink from the spring of love, and I attain what I seek and desire,

(Translation from Homerin, "Recalling You My Lord", 135, Arabic 148; al-Ba'uniyya, Dīwān Fayd al-Faḍl, Arabic, 137-8)

The symbolic 'breeze' is recurrently employed by the Sufi poet to represent a new dawning awakening her to the true nature of reality. It projects a vivid

(Symbols of Mystical Ecstasy and Divine Love...) Dr. Gehan Deeb 
and emblematic meaning. The "breeze of acceptance" or "pastures of acceptance" are indications for love and grace, unmerited ecstasy and "fruitful knowledge" bestowed upon 'A'ishah. When "the beloved's divine identity becomes clearer, ' $\bar{A}$ 'ishah's dhikr transforms the ancient poet's reverie and nostalgia [ancient is my tale of love for Him] into an act of Sufi recollection to purify the heart of selfishness and lead the way to a mystical epiphany where all things pass away in the "truth of Truth" (Homerin, 2013, 135, 137). 'A'ishah proceeds,

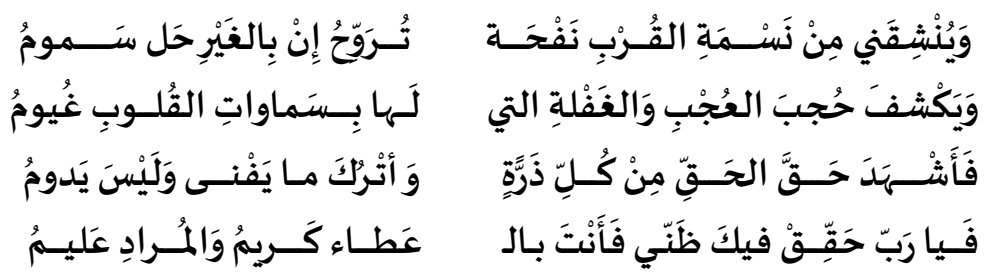

And He leads me to smell a scent on the breeze of nearness, reviving me, though the hot winds blow.

He tears away the veils of pride and heedlessness that cloud the skies of the heart,

So I behold the truth of Truth in every atom, and leave aside what passes and does not last.

O, Lord, confirm my view of You, for You are, indeed, all-knowing of needs, most generous with grace!

(Translation from Homerin, "Recalling You My Lord”, 135-6, Arabic 149; al-Ba'uniyya, Dīwān Fay ̣̣ al-Fạ̣l, Arabic, 38.)

The mystic tries to experience the moment of unveiling or ecstasy by revealing the mystery of this universe and the knowledge of the Truth and divine love, so he sees all beings, that which is, in nature and in the universe as a symbol or revelation (epiphany) for the Divine Self. Julian Young notes in Heidegger's Philosophy of Art that "to describe the poet's experience of the presence of the 'wonderfully all-present"' means, for 'Heidegger, "to share in the poet's 'epiphany', his ecstatic experience of the holiness of the world (in other words the festive mood that celebrates 'the wonder that around us a world worlds, that there is something rather than nothing, that there are things and we ourselves are in their midst'" (107).

Symbols and metaphors, implied or stated, are used to illustrate the phenomenon of realisation, or awakening. In his endeavour to seek the Truth, Heidegger in "What is Metaphysics" calls this type of sudden and acute awakening of transcendental experience as "original anxiety" which "reveals the nothing" lying 'within' all inner-worldly beings (104). It also "occurs only in rare moments" and "can awaken in existence at any moment. It needs

(Symbols of Mystical Ecstasy and Divine Love...) Dr. Gehan Deeb 
no unusual event to rouse it" (106). During this experience "beings as a whole become superfluous", "expressly as a slipping away of the whole" (102), and "pure Da-sein is all that is there" (Guilford 89). "This being beyond beings" Heidegger calls "transcendence" (103). The presence in the form of light is the manifestation of the Truth in the forms of His names in the universes, i.e., the manifestation of the Merciful Soul in which all beings are found. This 'manifestation or 'showing forth' is called epiphany, and "by Christian thinkers it was used to signify a manifestation of God's presence within the created world." "The stance of the Christian ecstatic toward God is either that of the infant toward a loving maternal parent or of a woman toward her lover." (Farber 215). The mystical experience of the union with the Absolute is, to the mystic poet rather than the ordinary man, actually and consciously "seen and felt" through a "state of an overwhelming sensation, the ecstasy of the moment" (Tülüce 11).

For the Sufis, the heart signifies God's house from which His light is revealed to the world.

Sufis have mastered the alchemy of the heart, through which the energy of love transforms the individual to reveal the light hidden within the darkness of the nafs or lower self. They developed a detailed science for working with the chambers of the heart to effect an inner transformation that gives the wayfarer access to the light of his true nature. ... [W] can use the tools of inner transformation to work directly with the soul of the world, to help the anima mundi reveal its divine light and awaken. (Vaughan-Lee)

Accordingly, 'A'ishah's epiphany or trancelike experience with the holiness is ecstatic in lyric as it brings the readers in closeness with the recollection of the Divine by a consciousness directly aware of His presence and His light. She writes,
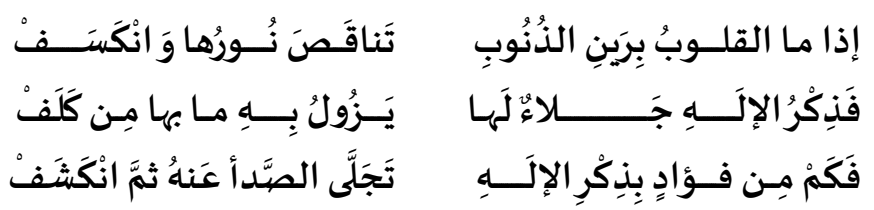

When sin soils the hearts, and their light grows dim and dark,

Then recollection of God is their polish wiping the spots away.

In recollection of God, how many hearts remove the rust, revealing the light within. 
(Translation from by Homerin, "Recalling You My Lord", 142, Arabic 149; al-Ba'uniyya, Dìwān Fayḍ al-Faḍl, Arabic, 110.)

In her pursuit for grace, 'A'ishah likens her mystical state to a life of everlasting happiness in the gardens of Paradise where God will reveal Himself to those who are saved. Allah Al-Mighty states in a Holy Saying (Hadith Qudsi) that He created the world by revealing His concealed nature, "I was a hidden treasure; I loved to be known. Hence I created the world so that I would be known." Accordingly, the images of the veil, or hijab, and the bridal chamber are also invoked in 'A'ishah's Emanations of Grace to signify anything that thwarts intimacy with the beloved. As a matter of fact, she "lived in a social context wherein what was perhaps most desirable and rarely attainable for [her] was not a beloved who would "unveil" himself to her, but a beloved who would be constant in his intimacy" (Dakake 83). She writes,

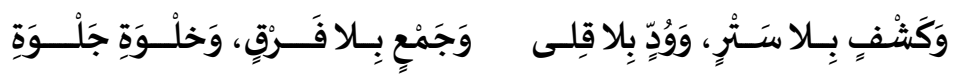

An illumination without a veil, love without hate,

Union without severance, and the seclusion of the bridal chamber

(Translation from Homerin, Emanations of Grace, 104; al-Ba'uniyya, Dīwān Fayd al-Faḍl, Arabic 241)

More importantly, at that moment of unveiling or illumination, when transformation happens, there exists an erotic element in the bridal chamber image to the nature of the union between the seeker and God, between the lover and the beloved. For Sufis, notably women, Dakake affirms,

Indeed, there are few powerful moments of sudden unveiling in the reports connected with Sufi women; and their sense of divine presence-while often described as inducing states of drunkenness or madness - does not reportedly come in the form of sudden, periodic irruptions into ordinary consciousness, but is rather portrayed as a state that is always available to them. They seem able to encounter this divine presence as a matter of course whenever the distractions of the day had settled and they could again attend to their most interior and ever-present "Guest.". (90)

However, we should take into account how 'A'ishah, dissimilar to Sufi poets, "does not claim complete annihilation nor does she articulate an experience of contrasting states. Rather, the experience of illumination, union, and love occurs without the need for its opposition" (Ullah 183). Hence, the main purpose of her mystical poetry is to express "an individualized experience of union that is simultaneously aware of its instructive-and therefore social-implications" (Ibid 184).

(Symbols of Mystical Ecstasy and Divine Love...) Dr. Gehan Deeb 


\section{3-3. Symbols of the Complete Divine Beauty:}

Symbolism is used by 'A'ishah and Yeats, both in mysticism and poetry, in the mystic and poetic contexts, to describe the moment of beauty or to express the spiritual ecstasy by terms of bodily love and passionate joy. Answering the question: "What is the difference between the light discovered in the depths of the psyche and the light of our transcendent divine Self glimpsed in meditation or other experiences?" Vaughan-Lee asserts that "It is the same light experienced in different ways. The Sufi knows that the Beloved, the source of all light, has both an immanent and a transcendent quality. He whom we love is both "nearer to him than his jugular vein" and "beyond even his idea of the beyond." The Self, "larger than large and smaller than small," has the same dual quality." (Vaughan-Lee 2). From this very light, 'A'ishah experiences beauty in the 'Divine presence.' In the Emanations of Grace, she describes "her love for God and union with Him":
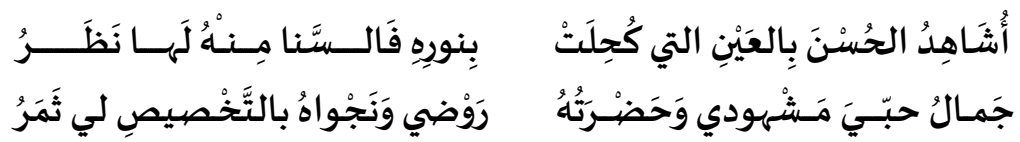

I behold beauty with eyes lined by His light, and His splendour was the eyes' sight.

My love's beauty is my vision, His presence my gardens, and their fruit is His love talk devoted to me.

(Translation from Homerin, Emanations of Grace, Fons Vitae, 2011; Al- Bā'ūniyyah, Dīwān Fayḍ al-Faḍl, Arabic 378)

Through symbols and signs associated with other symbols related to the timelessness of her soul, 'A'ishah formulates a visual richness found in the splendid imagery of the beauty of God or the Prophet Muhammad. Her love, expressed through her vision of the universe, includes every aspect of the existence. Elaborating, she attempts to give her vision a sensual form by alluding to her love of nature and its 'unchanging light' visible by heart (clear vision). Throughout, her experience is more than visual; it is evoked by the vivid descriptions of the image of the sun or moon beneath which lie the poet's gardens with their fruits that reflects the splendour and beauty of the Beloved, the Prophet, seen by eyes and felt by the heart.

As a matter of convention, 'A'ishah, influenced by her predecessors and Sufi masters, employed the motifs of recollection in her poems. She was inspired by Arabic rhetoric conveyed through echoes of Qașìdat al-Burdah by Muhammad al-Bușīī (d. 694/1295) whose prelude recalls the Prophet Mohamed as follows:

(Symbols of Mystical Ecstasy and Divine Love...) Dr. Gehan Deeb 


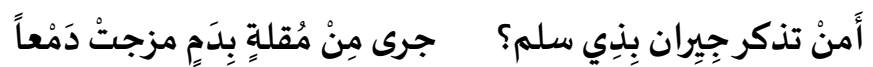

Was it by the memory of those you loved at Dhū Salam

That you wept until your tears mixed with blood?

Similarly, 'A'ishah's collection Al-Fath al-Mubin fi Madh al-Amin ("The Clear Inspiration in Praise of the Trusted Prophet") is modeled with the same meter and rhyme. However, unlike the conventional method of her predecessors, she openly praises the physical beauty of the Prophet Mohamed by likening it to the beauty of the moon:

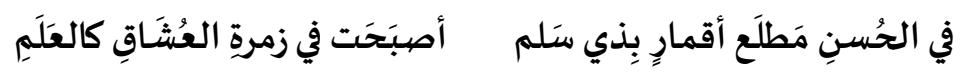

It is a felicitous opening with the moons of Dhū Salam

I have become a banner among the party of ardent lovers.

(Translation from Ullah, 138; See Al-Bā‘ūniyyah, Sharh Al-Badì 'iyyah alMusammāh bi-al-Fatḥ al-Mubìn fì Madḥ al-Amìn, ed. Riḍā Rajab, 33)

Earthly perfection, for 'A'ishah, is embodied, literally and physically, in the Prophet Mohamed's beauty and his great attributes.

\section{The 'symbolic system' of W.B. Yeats: ${ }^{2}$}

William Butler Yeats (1865-1939) is one of the greatest writers of the 20th century poetry that bridges the space between the Victorians and the moderns. Christian though he was, Yeats rejected orthodox Christianity in some respects. Yeats's individuation is represented in his rejecting to adhere to a precise religion or culture in his mystical thoughts. Though he is not known as a pure mystic, he believed in the 'unity of culture' and created his own religion out of a synthesis of traditions-Christian, Islamic and Hindu-to strengthen his desire for eternal spiritual truth, that greatly affected his poetic use of symbols and metaphors. His literary allusions to Buddhism and Hinduism were the source of the recurring symbols in his early works. He alluded to the symbols of Tantric Buddhism "many of which are thoroughly geometric in nature," as pointed out by Chanda-Vaz who adds, "geometric shapes take on deeply spiritual meanings and are accorded great importance in ritual and sadhana. While mantras are auditory manifestations of energy, yantras and mandalas form their visual counterparts" (Chanda-Vaz $15)$.

Yeats gradually became more interested in his own 'symbolic system' connected with mysticism, magic, visions, and allusions. Symbols for Yeats communicate the unsaying; they "convey to others (what he thought) what

${ }^{2}$ Yeats' poems pertinent to this study are taken from The Collected Poems of W. B. Yeats. Wordsworth Editions Limited, 2000.

(Symbols of Mystical Ecstasy and Divine Love...) Dr. Gehan Deeb 
could not otherwise be communicated. For him the employment of symbols was not only a poetic device; it was a kind of discipline." (qtd in Al Khafaji 53). A symbol, Yeats also believes, "is indeed the only expression of some invisible essence, a transparent lamp about a spiritual flame" (Ibid).

In his development as a poet and mystic, Yeats was greatly influenced in his earlier poems by Romantic writers, such as William Blake and Percy Bysshe Shelley, and in later works by Thomas Taylor Plotinus (205-270 A. D.). Yeats "derived the images of swan, fountain, cave, and tower, and the motif of the soul-allegorizing journey upon sea or river" from Shelley (Ross 548).

Being influenced by the famous Irish patriot John O'Leary, Yeats pervaded his early poems with symbols related to the Irish myths and Gaelic traditions:

As he lacked a firm faith in a stable religion, Yeats created a religion for himself in the Irish myth and legend. He turned Ireland into a dreamland, a Celtic utopia. This search led Yeats to various kinds of mysticism, to folklore, theosophy, spiritualism and Neo-Platonism. When he finally found Irish myth no longer sufficient to sustain his poetic impulse, he turned to himself for inspiration. In middle life he elaborated a symbolic system of his own. (Al Khafaji 54)

His father, a Protestant ecclesiastic, a man of reason and a sceptic, constantly urged Yeats to avoid his mystical ideas. One day, he sadly wrote to his son: "I am sorry you are returning to mysticism" (Murphy 485). "He continued to fire arrows into what he regarded as his son's most vulnerable area: I know that Blake's poetry is not intelligible without a knowledge of Blake's mystical doctrines. Yet mysticism was never the substance of his poetry, only its machinery... His mysticism was a make-believe, a sort of working hypothesis as good as another" (Ibid 444). However, it seems that Yeats kept on searching the subject, rather than attaining his father's desire or adopting his opposed views.

Nonetheless, beliefs aside, Yeats frequently and eventually uses various Judeo-Christian symbols, Biblical language and allegorical structure in his poems and plays to present a unique insight into the mystical states of divine love and ecstasy. The Rose Cross, for instance, is a significant symbol, known in the traditional Christian concepts as the Rosy/Rozy Cross. "In its fundamental form, at the centre of a six-squared cross is a red five-petalled rose ... thought to represent the human body, an unfolding of consciousness, a union of the rose female and the cross male, and silence/secrecy" (ChandaVaz 42). Joining the Hermetic Order of the Golden Dawn in 1890, Yeats became acquainted with a rich source of symbols, serving to represent the

(Symbols of Mystical Ecstasy and Divine Love...) Dr. Gehan Deeb 
inner self or the soul of the individual, and the occult. "Yeats's participation in Rosicrucian rituals," as White contends, "reinforced his growing awareness of the rose as a symbol of not only female sexuality but also perfect unity" (81). In Jungian terms, the image of the rose placed over the cross, White adds, signifies "the universe as a unity of opposites achieved at higher states of occult discipline" and simultaneously represents "the union of the sexes" (81).

Like Sufi mystics, the state of mystical ecstasy is not inconsiderable, not only in Christian mysticism, but in other religions and traditions. In fact, Yeats's acquaintance with Arabic literature, especially the works of the great Sufi, Ibn 'Arabi (d. 1240), gave his poems a symbolic framework borrowed from Sufi esotericism. Yeats's individuation is represented in his allusion to the body perfection and its union with the soul in a mystical marriage, more particularly in the notion of the Perfect Man or 'the finished man' - as defined by him in 'A Dialogue of Self and Soul' - who "is not the saint, but he is close to Ibn Arabi's 'the insanil-kamil' ... Man is created by God with a resemblance to His shape, and according to Ibn Arabi, 'the essential dignity of humankind resides in the fact that God, out of His love to be known, created man in His image" (Hayder 411-12).

For Yeats, earthly perfection is embodied in a tall and beautiful actress, Maud Gonne, whom he met in London and fell in love with though she refused his marriage proposals several times. He continued to court Gonne for nearly three decades; she became a symbol of Love in its perfection, shared Yeats's interest in spiritualism, and eventually formed a mystical marriage with him (Poetry Foundation 1). This mystical marriage, or bodysoul unity, is a recurrent theme and image in his famous poems.

The strong analogy between the mystic's quest for the Ultimate and the Heideggerian quest for Being is clearly reflected in Yeats's book A Vision (1925). The Ultimate, the highest sphere of his universe, "can be symbolised but cannot be known" (193) "due to people's own limitations". It "neither one nor many, concord nor discord, is symbolised as a phaseless sphere" (A Vision 193) ... [that] falls in human consciousness ... into a series of antinomies" (qtd in Tülüce 47, 187). Yeats was introduced to the mystical notion of Plotinus when he had married George Hyde-Lees in 1917 and they began doing automatic writing sessions and sharing a mystical marriage as well as other seemingly esoteric subjects. In his late poetry, he employs the concepts of Plato and Plotinus: hypostases, the emanation principle, transcendence, Unity of Being, and "the importance of memory and recollection in the upward path to union with the One" (Tülüce 41). Moreover, Yeats "adds his own twist to Plotinus' mystical universe, creating a slightly different

(Symbols of Mystical Ecstasy and Divine Love...) Dr. Gehan Deeb 
understanding of mysticism better suited and perhaps more easily applicable to his own world" (Ibid 8). His symbolic system includes his own "mystical cosmos'. Elaborating, Yeats "did not believe that the world is scattered into particular things; rather he maintained that the manifold of the world constitute but one unity. Again, he said that there were no different worlds: no scientific world, no philosophical world and no poetic world; but there was only one world" (Sarker 71).

In "Sailing to Byzantium" (1927), Yeats uses Byzantium as a symbol of the ultimate reality, the realm of the mystical state of union, and the transcendental world. He needs to purify a sick heart with desire as an escape from life. To become ecstatic in the mystical or spiritual journey is to abjure the involuntary bodily desires. The sailing metaphor represents this symbolic journey of the human soul. Just as Heidegger's quest for a timeless Being, for Yeats "the perfection of art stands timeless" (Henn 64); he seeks "spiritual redemption through the timelessness of art" (Ross 214). Yeats uses a new technique of allegorizing journey by sailing for spiritual rebirth, the first step of transformation, to relive in art, signified in the golden bird and in making the sages standing in God's holy fire. Yeats writes in "Sailing to Byzantium",

\author{
Things out of perfection sail, \\ And all their swelling canvas wear, \\ Nor shall the self-begotten fail \\ Though fantastic men suppose \\ Building-yard and stormy shore, \\ Winding-sheet and swaddling-clothes. (CP 163, 1-6)
}

He employs the symbol of sailing to reflect the emanation process and the quest for truth in a limitless space. Here emanation 'out of perfection' means ecstasy, being placed outside our selves and then returning, in a quite Platonic vein, for unity with the 'Divine Mind'. For Yeats, the binary between the old age and the passionate, and between art and philosophy, are created beyond temporality and spatiality to achieve unity. Yeats "achieved eternity in his own way: through his own ideas he could achieve this non-temporal or timeless unity in poetry or artistic space. Thus, he may be said to have transpositioned transcendence or blurred the boundaries between 'Here' and 'There,' or, in Neo-platonic terms, the empirical world and transcendence" (Tülüce 84).

\title{
4-1. Beauty, Body Perfection, and Unity of Being/Transcendental unity:
}

Like the Sufi poet 'A'ishah, the beauty of the beloved is represented metaphorically or figuratively through a set of vocabulary and symbols drawn from ordinary human romantic love. In Yeats's esoteric system in "The

(Symbols of Mystical Ecstasy and Divine Love...) Dr. Gehan Deeb 
Phases of the Moon," divine or complete beauty is the ideal model for another kind of beauty, very close to phase fifteen, "in which the Unity of Being is likely to occur. Leda and Helen's beauty is divine, and Yeats used that beauty for a comparison of the beauty of his beloved Maud Gonne in particular to the latter" (Hayder 407). He writes,

Robartes. All thought becomes an image and the soul

Becomes a body: that body and that soul

Too perfect at the full to lie in a cradle,

Too lonely for the traffic of the world:

Body and soul cast out and cast away

Beyond the visible world.

(CP "The Phases of the Moon" 139, 11, 60-65)

Out of divine limitless love, Yeats explains, the soul becomes the body and the thoughts become an image. The body-soul union comes to be 'Beyond the visible world,' or invisible. "Passion, or love in terms of the Unity of Being, takes on the major role in this process to transcend the body's limits to reach ecstasy" (Hayder 416).

"Among School Children" (1927), a poem included in The Tower collection, like "Sailing to Byzantium", depicts the dancer united with her dance in the so-called Unity of Being, or the mystical unity attained through memory and recollection of love. In a quite Heideggerian vein, Yeats seems to emphasize his thought of temporality when he remembers Gonne appearing in different times through three different forms. He composes his poem in the form of a dream-vision; it talks about an old man who dreams of a 'Ledaean body', a reference to Maud Gonne, the physical human embodiment of the ultimate beauty. This overt use of allegory denotes her non-temporal, mystical beauty. Yeats portrays the old man's dream as follows:

I dream of a Ledaean body, bent

Above a sinking fire, a tale that she

Told of a harsh reproof, or trivial event

That changed some childish day to tragedy -

Told, and it seemed that our two natures blent

Into a sphere from youthful sympathy,

Or else, to alter Plato's parable,

Into the yolk and white of the one shell.

(CP "Among School Children," 183, 9-16)

With respect to Heidegger's idea of temporality presence, Maud Gonne, in a symbolic dream, "appears to the old man beyond temporality in different ages both old and young at once and even back in ancient times

(Symbols of Mystical Ecstasy and Divine Love...) Dr. Gehan Deeb 
before mankind as it is known in modern days." Gonne also "becomes the Form Love that resides in the transcendental realm. It is the memory of Love that brings this mystical moment to the old man" (Tülüce 61-62). This notion of love memory is so reminiscent of Ibn al-Farid's and 'A'ishah's previously discussed notion of pre-eternity while drinking the wine of the love of preeternal life: in Ibn al-Fāriḍ's "before the creation of the vine," and in 'A'ishah's "love's heady wine before my birth, /And I delighted in my drink prior to my being." Elaborating, the mystical experience behind phantasmagorical scenes, images and symbols is literally expressed in the dreams, visions and prophecies of Yeats's poetry that combines reality and imagination simultaneously. More interestingly, he writes in "Among School Children":

Her present image floats into the mind-

Did Quattrocento finger fashion it

Hollow of cheek as though it drank the wind

And took a mess of shadows for its meat? (CP 184, 25-28)

Once again, Yeats asserts how the image of his beloved "floats into [his] mind". His spiritual experience surpasses and transcends the physical image of the body to approach the state of union in eternity. In the following section, Yeats proceeds,

Labour is blossoming or dancing where

The body is not bruised to pleasure soul,

Nor beauty born out of its own despair,

Nor blear-eyed wisdom out of midnight oil.

O chestnut tree, great rooted blossomer,

Are you the leaf, blossom or the bole?

$\mathrm{O}$ body swayed to music, $\mathrm{O}$ brightening glance,

How can we know the dancer from the dance?

(CP "Among School Children", 185, 57-64)

Here, the various images of Gonne are gathered within the dance metaphor of the final line. In the state of union, integration is attained when the dualistic form of the knower and the known, of the dancer and the dance, becomes invisible, and united in one ultimate, or as he regards, within the 'Divine Mind'. The 'midnight oil', the syrup of wisdom flowing out of the sacred bodies of the saints, is the immortal essence resulting from their bodysoul interaction. The saints are deep-rooted just like the symbolic chestnut tree whose trunk or 'body' is inseparable from its syrup, fruits, or essence, and is indeed a sign for the attraction of God's grace. Yeats's style is esoteric and symbolic in accordance with his view about the 'changeless' or 'undecayed' body of Christian saints like St. Rosencreutz, St. Theresa, and

(Symbols of Mystical Ecstasy and Divine Love...) Dr. Gehan Deeb 
St. Catherine of Genoa (Hayder 408); and "characters from other faiths or a recurrent Leda in Yeats's poem, "Leda and the Swan" who is pagan, and Kusta's bride in "The Gift of Harun Al-Rashid" who is presumably Muslim." This view evolves as he fears the loss of "his body's energy. The withered body of his beloved was one of the elements that caused a waning love." Actually, he considers the body not "as evil or as a prison for the soul" as in Gnosticism; rather he deifies it as "blessedness comes from the interaction between body and soul." (Ibid 415-16).

In a similar context, Yeats's view of spiritual dancing is evoked in a passage from his poem "The Double Vision of Michael Robartes", which reveals the poet at his best:

O little did they care who danced between,

And little she by whom her dance was seen

So she had outdanced thought.

Body perfection brought, (CP 145, 11, 37-40; Hayder 406)

Evidently, Yeats here asserts that the idea of salvation can be merely crystallized and even attained in two ways: by spiritual dancing through "body perfection" and "by the "intellectual fire" which is symbolic of a purge of the soul or mind" (Hayder 416). The body of the dancer, the beloved of Michael Robartes, is again very reminiscent of the "Ledaean body", related to the spiritual as well as the physical realms. His poem "Vacillation" also presents the flame/ 'flaming' as symbolic to 'purge' the soul:

I

BETWEEN extremities

Man runs his course;

A brand, or flaming breath.

Comes to destroy

All those antinomies

Of day and night;

The body calls it death,

The heart remorse.

But if these be right

What is joy? (CP 212, I, 1-10)

The lines reveal the concrete vision of the poet through countless symbolic expressions, the 'flaming breath' and twin symbol of day and night are the most significant through which one can feel and see the moment of illuminating truth. Yeats gives constantly rapturous expressions to convey honestly something experienced by him. In "Vacillation" he talks about the sudden phenomenon of mystical ecstasy, 'What is joy?' that does not last 'but

(Symbols of Mystical Ecstasy and Divine Love...) Dr. Gehan Deeb 
knows not grief' (Pratt 84). For him, blessedness derives from this massive rapture:

It seemed, so great my happiness,

That I was blessed and could bless. (CP 214, IV, 42-3)

The tree, as regarded by Christina Pratt in An Encyclopedia of Shamanism II (2007), is a recurring symbol with different interpretations in different cultures. Whereas the Sufi poet 'A'ishah uses it for the purpose of God's grace, Yeats uses the tree of Life/knowledge of the Cabbalistic and Shamanistic cultures to refer to the fruit of joy. In fact, he writes:

II

A tree there is that from its topmost bough

Is half all glittering flame and half all green

Abounding foliage moistened with the dew;

And half is half and yet is all the scene;

And half and half consume what they renew, And he that Attis' image hangs between

That staring fury and the blind lush leaf

May know not what he knows, but knows not grief.

$$
\text { "Vacillation" (CP 212, 11, 11-18) }
$$

Actually, the Jewish Cabbalah mysticism "provided a symbol system, a paradigm for cross-referencing symbols, and several methods of esoteric exegesis that were applied to an otherwise objective curriculum of fairly exoteric material" (Mann et al. 309). Depicting the emanation of light, Yeats skillfully uses Sephirot as a diagram consisting of ten circles that represent ten divine cosmic attributes-the same symbol of the Hermetic Order of the Golden Dawn that Yeats has joined and from which he has acquired a variety of symbolic sources. Yet, generally speaking, "the Tree of Life represents the connection between the physical and spiritual worlds. It is also known as World Tree, Cosmic Tree, World Axis, Great Tree, etc." (Chanda-Vaz 36)

Furthermore, in "The Gift of Harun Al-Rashid," according to Kusta bin Luka, the Caliph's Christian translator and philosopher, the beauty of a woman's body is the source of wisdom.

The signs and shapes;

All those abstractions that you fancied were

From the great Treatise of Parmenides;

All, all those gyres and cubes and midnight things

Are but a new expression of her body

Drunk with the bitter sweetness of her youth.

And now my utmost mystery is out.

A woman's beauty is a storm-tossed banner;

(Symbols of Mystical Ecstasy and Divine Love...) Dr. Gehan Deeb 
Under it wisdom stands, and I alone --

Of all Arabia's lovers I alone --

Nor dazzled by the embroidery, nor lost

In the confusion of its night-dark folds,

Can hear the armed man speak.

(CP "The Gift of Harun Al-Rashid" 383, 204; Hayder 402-406)

It is especially significant that Yeats has mentioned in a footnote that the diagrams, signs, shapes, gyres, and cubes are geometrical figures or forms drawn by the wife of Kusta bin Luka while asleep. These forms are exquisitely interconnected in a recurring pattern with the automatic writing of Yeats's wife who acted as a medium for spirits, culminated in the publication of his book $A$ Vision. Likewise, there is "an increasingly violent association of the antinomies between the physical and the spiritual sides of love. Once so despoiled, love must become mystical again" (Henn 71). Bitter and sweet, juxtaposed in his sentence 'Drunk with the bitter sweetness of her youth,' are signaled out for attention. A similar connection of body and soul is evoked in another passage from "The Gift of Harun Al-Rashid,"

'What matter if our souls

Are nearer to the surface of the body

Than souls that start no game and turn no rhyme!

The soul's own youth and not the body's youth

Shows through our lineaments. My candle's bright,

My lantern is too loyal not to show

That it was made in your great father's reign,

And yet the jasmine season warms our blood.' (CP 380, 67-74)

In terms of erotic imagery, in Yeats's later poems that combine sexual ecstasy and mystical ecstasy, he used the gyres, stairs, towers and spheres as a group of related central symbols and images that depict-in a metaphorical sense-the connection and the 'conscious movement' between the physical realm and the spiritual realm, between the earth and the heaven, that is the unity of body and soul, male-female union. In both the wide and narrow senses, the image of the gyre, or the whirling cone, is, so-to-say, an extended image through which the seeker can reach the Absolute, and it is simultaneously connected with the male-female union symbol, or the anima mundi concept - the 'Soul of the World' as foreshadowed in ancient philosophy and alchemy. "The representation of sexual union with a fitting set of symbols could, then, symbolize the perfect unity that Yeats was seeking" (White 77). In his poem "Chosen," included in the "Woman Young and Old" sequence, Yeats maintains that "the first experience of sexual love between a woman and a man is equated with the union of souls in heaven,

(Symbols of Mystical Ecstasy and Divine Love...) Dr. Gehan Deeb 
and the figure of the gyre is transformed from a spiraling zodiac into a cosmic sphere, [...] a symbol of perfect harmony" (Pratt 85). Yeats, in one of his letters to Olivia Shakespear (1926), confesses: "One feels at moments as if one could with a touch convey a vision - that the mystic way and sexual love use the same means - opposed yet parallel existences." Yeats then "was using his gyres as stairways from earth to heaven and back again" (Pratt 86).

Yeats shows a deep interest in other forms of mysticism, such as Eastern and South-Eastern mysticism in developing the theme of ecstasy out of spirituality. One deep area of concern throughout Yeats's poetry is the question of the visible and ecstatic connection of the physical and spiritual worlds. In his poem "A Dialogue of Self and Soul" he claims,

$\underline{\text { I am content to live it all again }}$

And yet again if it be life to pitch

Into the frog-spawn of a blind man's ditch,

A blind man battering blind men;

Or into that most fecund ditch of all,

The folly that man does

Or must suffer, if he woos

A proud woman not kindred of his soul.

I am content to follow to its source

Every event in action or in thought;

Measure the lot; forgive myself the lot!

When such as I cast out remorse

So great a sweetness flows into the breast

We must laugh and we must sing,

We are blest by everything,

Everything we look upon is blest. (CP 199-200, II, 57-72)

Although Yeats does not believe in the Samsara doctrine, he found in it a compensation for the concept of the Unity of Being in which "the interaction between body and soul is functioned or transcended by sexual intercourse to reach a unity with God," and as regarded by Doug Keller, in The Heart of the Yogi (2007), Yeats like 'the hatha yogis' "believed in the possibility of transforming the physical body into a 'divine' body-the Siddha" (qtd in Hayder 406). In "A Dialogue of Self and Soul", ultimate blessedness and ecstatic joy can be attained through the act of re-living. In his pursuit of mystical experience, Yeats repeats twice that he is 'content to live it all again', and he is 'content to follow to its source'. Probably, this repetition gives away more than he intended, for the feelings of ecstasy, as pointed out by Leech, are "too great for expression in few words." (78). The powerful effect of intermittent repetition seems to be the "reflection on the

(Symbols of Mystical Ecstasy and Divine Love...) Dr. Gehan Deeb 
inadequacy of language to express what you have to express 'in one go"' (Leech 79).

It is important to mention that Yeats also draws upon the "Sufi treatment of the erotic, which communicated material as well as metaphysical yearning through symbolic representations of the body, masculine and feminine beauty, intoxication, and desire in terms of eternal time" (Ullah 73). Generally speaking, this use of symbols implies a deeper mystical interpretation behind their meanings. In a special sense, the body-soul union, or the image of the finished man, namely "body perfection" is clearly presented by "Yeats's use of sexual union as a symbol of the resolved antinomies" (White 88). Yeats suggests that "religious or mythological symbols have sexual meanings; and that cycles and antinomies represent, symbolically, the conflict and union of the archetypal male and the archetypal female. (The Poet as a Mythmaker, p. 35)" (qtd in White 76). The "concept of the rose as the archetypal symbol of woman and her sexuality" is again emphasized by Yeats. White adds that according to Freud, "blossoms and flowers in general represent the female sexual organs and that the shape of the rose suggests the vulva." Elaborating, Jung "in a more traditional vein says that the rose's circular shape also indicates unity or wholeness." (White 81-2). When Yeats repeats the word 'blossom' several times in the same stanza it carries a suggestion of the ecstasy of individuation derived from the union of earth and heaven, male-female sides. In Jungian terms, and in response to such sexually explicit and implicit images, the unconscious is brought to the conscious where anima and animus are united.

In "The Blessed", Cumhal inquires as to who is most blessed: "Is it these that with golden thuribles/ Are singing about the wood?" "blessedness goes where the wind goes," Dathi answers and proceeds:

And when it is gone we are dead;

I see the blessedest soul in the world

And he nods a drunken head.

0 blessedness comes in the night and the day

And whither the wise heart knows;

And one has seen in the redness of wine

The Incorruptible Rose. (CP 56, 29-36)

The passage genuinely describes blessedness that "one has seen in the redness of wine" that is symbolized by "The Incorruptible Rose" and "whether that of Bacchus or of Christ. Yeats's rose has at last become as completely sensual as it is divine" (White 42-44). His use of symbolism is similar to that of the Sufis and Christian mystics in some respects. Of particular interest is his

(Symbols of Mystical Ecstasy and Divine Love...) Dr. Gehan Deeb 
relatedness to Dionysus (Bacchus) - the Greek god of wine, fertility and intoxication - that emphasizes his acquaintance with the ecstasy phenomenon.

The same symbol of the rose will continue to be important and recursive throughout Yeats's earlier poems, such as "The Secret Rose" in which the rose bears directly upon its meaning as spiritual or "inviolate". Yeats writes:

... I, too, await

The hour of thy great wind of love and hate.

When shall the stars be blown about the sky,

Like the sparks blown out of a smithy, and die?

Surely thine hour has come, thy great wind blows,

Far-off, most secret, and inviolate Rose? (CP 57, 27-32)

It is crystal clear that Yeats's open question about the rose is beyond temporality and an allusion to Maud Gonne who is so pretty yet unattainable. His spiritual dimension is greatly influenced by the interaction between the body and soul that elevates her body to a divine state. In the previous lines, "Yeats's rose once again expresses his interest in the spiritual realm and unity" (White p. 52-4). They are most powerfully symbolic in elevating the 'undecayed', 'inviolate' and 'incorruptible' body, and in his mingling of antinomies, e.g., "love and hate" recalling the individual experience of the "bitter sweetness of her youth" in "The Gift of Harun Al-Rashid" (CP 383).

\section{4-2. Ecstasy of Suffering:}

Although Yeats "was basically a mystic, he was active in worldly matters. His antithetical self is present here" (Sarker 21). In "Crazy Jane", included in The Winding Stair and Other Poems collection (1933), Yeats explains his sexual charge by describing "Crazy Jane" sequence of seven poems as 'exciting and strange. Sexual abstinence fed their fire-I was ill and yet full of desire. They sometimes came out of the greatest mental excitement I am capable of' (L 814). In this context, he depicts Jane as a bold woman who can speak on "matters of great importance-ethical, metaphysical and ontological—such as bodily and spiritual love, man's relation to God and the nature of being" (Dabic 176).

In his essay "The Mandukya Unpanished" (1935), Yeats further asserts that he uses the Tantric elements in the Crazy Jane poems. To approach the ultimate Self and experience a mystical vision "through a transfiguration of sexual desire", as in "Tantric philosophy, where a man and woman, where in sexual union, transfigure each other's images into the masculine and feminine characters of God...the man seeks the divine Self as present in his wife, and

(Symbols of Mystical Ecstasy and Divine Love...) Dr. Gehan Deeb 
the wife the divine Self as present in her man" (qtd in Dabic 177). In "Crazy Jane on the Day of Judgement," Yeats writes,

"Love is all Unsatisfied

That cannot take the whole

Body and soul";

And that is what Jane said. (CP 219)

Useful as it is to trace the erotic and spiritual dimensions throughout the Crazy Jane Sequence. In this respect, Yeats, on the tongue of the amoral Jane, evidently considers both body and soul to be equally important in the process of integration or union of love. "In Tantric terms, the ostensible duality of things is resolved in the union Jane proposes in which Shiva and Shakti are the two aspects of the Self. The eroticism of that union becomes a ritual that integrates gender differences in the Absolute" (Dabic 178). The body and soul dualism is present; "while the former is subject to aging, the latter transcends time, so they can hardly be on the same footing until the annihilation of time" (Ibid) on the Day of Judgement.

"What can be shown?

What true love be?

All could be known or shown

If Time were but gone."

"That's certainly the case," said he. (CP 219)

In his poem "Crazy Jane Talks with the Bishop," the Bishop sees Jane and her 'dear Jack' 'lived like beast and beast' in their pursuits of erotic ecstasy. This image conveys a necessary fulfilment, however repulsive; Jane has learned through bodily desires that 'fair needs foul,' i.e., the importance of erotic dimension within the spiritual realm. In order to attain a mystical experience, bodily desires (lowliness) and mystical love must be merged together; otherwise, true love is not fulfilled.

'A woman can be proud and stiff

When on love intent;

But Love has pitched his mansion in

The place of excrement;

For nothing can be sole or whole

That has not been rent.' (CP 221)

Jane believes that to be 'whole' (divine) by achieving bodily pleasure, she must lose her virginity 'rent'. In this regard, Corcoran points out,

There is a sexual ambivalence about the word 'stiff', since it is more usually applied to men than to women when engaged in the act of love; and when the word 'love' moves, as it does, from lower case in

(Symbols of Mystical Ecstasy and Divine Love...) Dr. Gehan Deeb 
the second line to upper case in the third, it carries suggestions of a move from sexual or secular love to divine love since, as the Bishop will know, 'God is Love' (15).

Accordingly, Jane elevates the erotic to the sanctity of the spiritual realm because nothing can be 'sole or whole' unless that undergoes suffering of the body for spiritual salvation; it is once again "the bitter sweetness of her youth." (CP "The Gift of Harun Al-Rashid" 383)

\section{4-3. Ecstasy of Death:}

A symbol for the mystic may refer to its opposite; death signifies a new life, and joy is implied in sorrow, happiness in sadness, and relief in toil. Yeats writes in his 'A General Introduction for My Work' "praising Lady Gregory's remark that 'Tragedy must be a joy to the man who dies' ... the nobleness of the arts is in the mingling of contraries, the extremity of sorrow, the extremity of joy, the perfection of personality, the perfection of its surrender, overflowing turbulent energy, and marmorean stillness" (255). In his symbolic play, The Shadowy Waters, known as 'The Cruise of the Soul in Search of an Impossible Love', Yeats describes the symbology of the relation of man and woman. He confesses, on the tongue of Forgael who enchanted Dectora to lead her to the end shadows and dreams, that ecstasy is the impossible joy that can only be felt in terms of the apocalyptic imagery and diction of death when a timeless unity is attained. Yeats writes,

FORGAEL - Where the world ends

The mind is made unchanging, for it finds

Miracle, ecstasy, the impossible hope,

The flagstone under all, the fire of fires,

The roots of the world.

For it is love that I am seeking for

But of a beautiful unheard of kind

That is not in the world. (CP "The Shadowy Waters," II, 353)

The death-wish imagery is repeated in Yeats's poetry as well. It is important to mention that in the first stanza of his elegy for the young fighter in WWI "An Irish Airman Foresees His Death" (1919), Yeats metaphorically declares his own perspectives of his death, 'meet[ing] his fate,' on the tongue of Major Robert Gregory:

I know that I shall meet my fate

Somewhere among the clouds above;

Those that I fight I do not hate

Those that I guard I do not love; (CP 111, 1-4).

(Symbols of Mystical Ecstasy and Divine Love...) Dr. Gehan Deeb 
In these opening lines, the chiasmus, parallel structure and antithesis do not merely assert his indifferent feelings towards enemies or fellow citizens at war; rather, they emphasize a deeper motive, his ecstatic yearning for a death interconnected with the language of music. In a contrastive connection, the verbal repetition in 'Those that I fight' and 'Those that I guard' is "audible to the listener, and visible to the reader. This means that the parallelism sets up a special relation between expression and content; the outer form of the message not only expresses underlying meaning but imitates its structure" (Leech 85). The political is weaved with the mystical ecstasy in the act of a magnificent flight by a plane in a boundless and limitless space. The time and place of the pilot's death are unidentified, but he is certain that death is imminent. In Heideggerian terms, Yeats also admits that the past and future are brought all to the present.

I balanced all, brought all to mind,

The years to come seemed waste of breath,

A waste of breath the years behind

In balance with this life, this death. (CP 111, 13-16)

The poem ends in a sense of anxiety or elegizing as an important part of the ecstasy that arises from the moment at which the speaker can attain his desire of free flight in the clouds, or be placed there, with no boundaries or limits. The structure of death is prefigured: "Being-toward-its-end becomes phenomenally clearer as a being toward the pre-eminent possibility of beingthere" (Heidegger, Being and Time 232). It reveals the "lonely impulse of delight" that he can enjoy in his journey to heaven seeking the ultimate truth.

Concluding, the uniqueness and individuation of Yeats's poetry are manifested in a combination of multiple cultures and styles of writing. $\mathrm{He}$ was significantly interested in employing different poetic and symbolic methods, each of which has been widely used by him as a lyrical and reflective poet.

\section{Conclusion:}

This paper has attempted to demonstrate that 'A'ishah al-Ba'uniyya and W.B.Yeats, employ a wide range of mystical symbols of divine love and ecstasy in their poetry with a view to showing how they reflect a unique insight and indirect truths. Within the scope of this study, some conceptions have been explored. The subject is two-fold; one is devoted to the Heideggerian thinking model constructed as a framework to examine the artistic and mystical aspects of the poetry of Yeats and 'A'ishah. The other is a psychological one from Jung's concept of individuation and the use of archetypes and symbols from myths and the past; namely, the union of

(Symbols of Mystical Ecstasy and Divine Love...) Dr. Gehan Deeb 
conscious and unconscious, soul and body, and male and female. It is evident that the life and personal experiences of both writers have shaped their mystical and artistic journey of individuation and have been the chief parameters through which their poems have been investigated. Equally important is their draw on their poetic predecessors-for Yeats, Romantic poets and Plotinus, for 'A'ishah, Ibn al-Farid.

There is no denying that the mystical pursuit of 'A'ishah and Yeats is all the stronger in their artistic and symbolic forms. Though the poetic language of mysticism is often difficult, figurative, ineffable, and idiosyncratic, both succeeded in composing a detailed account of their spiritual experiences through employing a variety of symbols, poetic techniques, narratives and mystic themes. 'A'ishah's and Yeats's poetic careers feature and make a powerful connection with the primary concepts and symbols of mysticism, both of Islamic and Christian origins: the ecstasy of union, accompanied by practices and love-related symbols and images. Both of them evolved a new style asserting that nature provides handy and accessible images for precognizance of earthly life, "before [their] birth" or "until the annihilation of time," and for mental concepts, suggesting that this makes their restoration complete as there exists a consciousness of the egoself in love and union. In a Heideggerian vein, this love transcends time and place even in contemplation and recollection, in addition to illumination, epiphany, the awakening experience or 'original anxiety' by which dasein is revealed to itself in its transcendence and Being itself can be experienced. The uniqueness, exceptionalism or individuation of their poetic mystical experience in resorting to the symbolic-wine, roses or blossoms, the sun and the moon, woman, and mystical marriage, undecayed body, flight, sailing and geometric shapes- may formulate a more different artistic reality than Sufi men's poetry in 'A'ishah's case, and represent a break from the adherents of Gnosticism in Yeats's case.

As mystic poets, they shared a dedication to the traditional themes peculiar to the understanding of ecstasy, e.g., union with God, intimacy, and intoxication. These are drawing out their similarities and differences. Yet both writers simultaneously went their different ways with the emphasis on how their symbols/concepts are aestheticized in their poetry, the subject of enquiry.

'A'ishah's and Yeats's crystallisation of their specific mystical states in verse reflects that both have attained intimacy, proximity, union and love of God, selflessness, blessedness, salvation, light, beauty and grace, and indeed with abundant shares of the epiphanies. For Yeats and 'A'ishah, as for Jung, the idea of individuation is represented in their allusion to the body

(Symbols of Mystical Ecstasy and Divine Love...) Dr. Gehan Deeb 
perfection and its union with the soul in a mystical marriage, echoing Ibn Arabi's notion of the al-insanil-kamil, the Finished or Complete Man. They allude to the Sufi and Christian spirituality and explores their basic principles though they do not directly reflect any recognition of orthodox beliefs in their works; rather, they prefer to be involved in social matters not to withdraw from society.

Briefly, Yeats is not known as a pure mystic, as 'A'ishah is. Christian though he was, Yeats created his own religion out of a group of traditions together to strengthen his desire for eternal spiritual truth. However, he frequently uses various Christian symbols, Biblical language and allegories in his poems and plays. Beside Yeats's representation of some of the Cabbalistic and Islamic precepts, he is sympathetic to Buddhism and Hinduism and always alludes to the union of the physical and spiritual realms. His poetic symbols are also derived from the Greek and Irish heroes and mythology, motifs, or mysteries. In this paper, some selected poems by W.B. Yeats have been subjected to close analysis, among which are: "Sailing to Byzantium", "Among School Children", the "Crazy Jane" and "A Dialogue of Self and Soul," "Vacillation," "The Gift of Harun Al-Rashid", and his symbolic play "The Shadowy Waters".

In most of his poems, however, Yeats is inspired by his own mystical philosophy, which sometimes differs slightly from 'A'ishah's. The notion of the masculine Divine Beloved is metaphorically conceived in 'A'ishah's poems; whereas the Divine Beloved is frequently reflected in the physical beauty of Maud Gonne and elevates her from the state of human to the state of Divine in Yeats's poems such as "The Secret Rose" and "Crazy Jane" poems. For 'A'isha, the Divine Beloved is symbolically masculine objectivized, and conversely, for Yeats is a feminine Beloved. Both suggest that there exists a divine "veiled" beloved, though different in gender.

Yeats was interested in arranging binaries into a particular togetherness or antinomies. As for Yeats, his poetry reflects the dualism of the body and soul. In his early poems, he metaphorically emphasizes the outward physical journey as an expression of his inward spiritual journey, like many mystics in different cultures. His extensive and diverse use of the images and symbols is the result of a profound influence on his thoughts of the transcendental state and unity of Being, and the importance of memory and recollection in the upward path to union with the One.

Nevertheless, in 'A'ishah's case, like most Sufi women, the spiritual journey was both symbolically and physically an inward spiritual path. In her self-created spiritual system, she as a seeker gets intoxicated by the wine in an allegorical journey to reach the Ultimate. Intoxication and drunkenness

(Symbols of Mystical Ecstasy and Divine Love...) Dr. Gehan Deeb 
symbols are widely used with their relatedness to other symbols such as the bar, the tavern, the cupbearer, and the beloved within religious and social contexts. In addition, other significant symbols include the heart of the seeker that signifies God's house; the veil that represents hindrance of God's union; the tree that symbolizes God's grace; the breeze for new awakening to the real nature of life; and the moon that represents beauty. 'A'ishah is exceptionally creative in her poetic mystical experience, succinct language, and rhetoric talent. To sum up, the poems attributed to 'A' ishah, in this paper, are those mostly published in the collection Fayd al-Fadl waJam' Al-Shaml ("Emanations of Grace and the Gathering Union"), her guidebook $\mathrm{Al}$ Muntakhab fì Ușūl al-Rutab fì 'Ilm al-Tașawwuf ("The Principles of Sufism"), and Al-Fath al-Mubin fi Madh al-Amin ("The Clear Inspiration in Praise of the Trusted Prophet"). They recount her feelings of intimacy and nearness to God and Prophet Muhammad, the most desirable state along the mystical path. 


\section{Works Cited}

Abram, D. The Spell of the Sensuous: Perception and Language in a More-ThanHuman World. New York: Vintage Books (eBooks), 1997. The Spell of the Sensuous: Perception and Language in a More-Than-Human World (harvard.edu). Accessed 15 April 2020.

al-Ba'uniyya, 'A'ishah. Bad̄̄ 'iyyat Al-Fath Al-Mubīn Fī Madh Al-Amīn Lil-Shā 'irah Al-Badā'i 'ìyah. 'Ammān, Jordan: Ministry of Culture, 2008.

al-Ba'uniyya, 'A'ishah. Sharh al-Badī'iyyah al-Musammāh bi al-Fath al-Mubīn fì Madh al-Amīn, edited by Rị̣ā Rajab, Dimashq: Rand lil-Ṭibā'ah wa al-Nashr wa al-Tawzī', 2010.

al-Ba'uniyya, 'A'ishah. Fayḍ al-Faḍl wa Jam' Al-Shaml. Bayrūt: Dār al-Kutub al'Ilmiyyah, 2010.

al-Ba'uniyya, 'A'ishah. Emanations of Grace: Mystical Poems by 'A'ishah AlBa'uniyya (d. 923/1517). Translated by Th. Emil Homerin, Louisville, KY: Fons Vitae, 2011.

al-Ba'uniyya, 'A'ishah. Al-Muntakhab fì Ușūl al-Rutab fì 'Ilm al-Tașawwuf, investigated by Th E. Homerin. New York: Library of Arabic Literature, 2014. https://www.libraryofarabicliterature.org/assets/Homerin-Principlesof-Sufism-Arabic-only-corrected-version.pdf. Accessed 7 July. 2020.

al-Ba'uniyya, 'A'ishah. The Principles of Sufism. Translated by Th. Emil Homerin, New York: NewYork University Press, 2016.

Al Khafaji, Saad Najim. "Old Age As a Motif In the Poetry of W.B. Yeats (18651939)". Journal of the College of Languages (JCL) Măgallä̈ Kulliyyä̈ AlLugiat, no. 17, June 2007, pp. 53-66. http://jcolang.uobaghdad.edu.iq/index.php/JCL/article/view/483. Accessed 12 June. 2020.

Capps, W.H., and W.M. Wright, editors. Silent Fire: An invitation to Western Mysticism. New York: Harper \& Row, 1978.

Chanda-Vaz, Urmi. "Sacred Shapes." PG Diploma in Mysticism, 2014-15, Department of Sanskrit, University of Mumbai. Academia.com, https://www.academia.edu/11917369/Mysticism_and_Symbolism. Accessed 8 March 2020.

Columbia Electronic Encyclopedia. 6th ed., Copyright (C) 2012, Columbia University Press.

https://www.infoplease.com/encyclopedia/religion/other/general/mysticism/t he-nature-of-mysticism. Accessed 10 Aug. 2020.

Corcoran, Neil. Poets of Modern Ireland: Text, Context, Intertext. Carbondale and Edwardsville: Southern Illinois University Press, 1999.

Dakake, Maria. "Guest of the Inmost Heart": Conceptions of the Divine Beloved among Early Sufi Women." Comparative Islamic Studies, v. 3, no. 1, oct. 2008, pp. 72-97.

(Symbols of Mystical Ecstasy and Divine Love...) Dr. Gehan Deeb 
https://doi.org/10.1558/cis.v3i1.72. https://journals.equinoxpub.com/CIS/arti cle/view/4725. Accessed 24 Jul. 2020.

Dabic, Snezana. W.B. Yeats and Indian Thought. A Man Engaged in that Endless Research into Life, Death, God. UK: Cambridge Scholars Publishing, 2016.

Farber, Sharon Klayman. Hungry for Ecstasy: Trauma, the Brain, and the Influence of the Sixties. Lanham, MD: Jason Aronson, Rowman \& Littlefield, 2012.

Guilford, Jeff. "Was Heidegger a Mystic?" Explorations, vol. 6, 2011, pp. 86-93. jeffguilford.pdf (uncw.edu). Accessed 12 April 2020.

Hayder, Faisal Abdul-Wahhab. "The Body-Soul Interaction in W. B. Yeats's Poetry: A Spiritual Way." Journal of Al-Frahedis Arts, Issue no. 29, 2017, pp. 402418. DOI: http://dx.doi.org/10.25130/art.v0i29.266. View of The Body-Soul Interaction in W. B. Yeats's Poetry: A Spiritual Way. Accessed 20 June 2020.

Heidegger, Martin. Discourse on Thinking. New York: Harper \& Row Publishers, 1966.

Heidegger, Martin. "Letter on Humanism.” Translated by Frank A Capuzzi, 1949. http://www2.hawaii.edu/ freeman/courses/phil360/17.\%20Heidegger's\%20 Letter\%20On\%20Humanism.pdf. Accessed 11 Jan. 2020.

Heidegger, Martin. Being and Time. Translated by Joan Stambaugh, New York: State University of New York Press, 1996 [originally written 1927].

Heidegger, Martin. Basic Writings: From Being and Time (1927) to The Task of Thinking (1964), edited by David Farrell Krell, Toronto: Harper Perennial, 2008 [ $1^{\text {st }}$ edn. 1993].

Heidegger, Martin. "Letter on Humanism.” Basic Writings, edited by D.F. Krell, Toronto: Harper Perennial, 2008 [originally written 1949], pp: 213-66.

Heidegger, Martin. "What Is Metaphysics?” Basic Writings, edited by D.F. Krell. Toronto: Harper Perennial, 2008 [originally written 1929], pp: 89- 110.

Henn, Thomas Rice. The Lonely Tower: Studies in the Poetry of W. B. Yeats. Routledge: Routledge Revivals, 2011.

Homerin, Th. Emil. 'Umar Ibn Al-Fāriḍ: Sufi Verse, Saintly Life. New York: Paulist Press, 2001.

Homerin, Th. Emil. "Living Love: The Mystical Writings of 'A'ishah al-Ba'uniyya (d. 922/1516)." Mamlūk Studies Review, USA: University of Chicago (MEDCO), 2003, pp. 211-234. http://mamluk.uchicago.edu/MSR_VII1 2003-Homerin_pp211-234.pdf. Accessed 11 April 2020.

Homerin, Th. Emil. "Recalling You, My Lord": 'A'ishah al-Ba'uniyya on Dhikr." Mamlūk Studies Review, University of Rochester, vol. 17, 2013, pp. 130-154. https://mamluk.uchicago.edu/MSR XVII 2013 Homerin pp130-154.pdf. Accessed 14 Sept. 2020.

Jung, Carl G. Memories, Dreams and Reflections, recorded and edited by Aniela Jaffe, translated by Richard and Clara Winston, New York: Vintage Books, 1989 [Originally written 1963].

(Symbols of Mystical Ecstasy and Divine Love...) Dr. Gehan Deeb 
Leech, Geoffrey N. A Linguistic Guide to English Poetry. London: Longman, 1969. Mann, Neil, Matthew Gibson, and Claire Nally, editors. Yeats, W. B. Yeats's "A Vision": Explications and Contexts. Clemson, SC: Clemson University Press, 2012.

Murphy, William M. Prodigal Father: The Life of John Butler Yeats (1839-1922). NewYork: Syracuse University Press, 2001.

Nel, John. "Mysticism." Bible Research, 12 2016. http://johnnel.com/2016/12/12/mysticism/. Accessed March 2, 2020.

Nixon, Laurence. The mystical struggle: A psychological analysis. Unpublished doctoral dissertation, Concordia University, Montreal, Quebec, 1990. http://positivedisintegration.com/NixonThesis.htm The mystical struggle: A psychological analysis (positivedisintegration.com). Accessed 10 June 2020.

nomindsland.blogspot.com. 'A'ishah al-Ba'uniyah: The tavern of Joy. March, 2016. http://nomindsland.blogspot.com/2016/03/'A'ishah-al-bauniyah-tavern-ofjoy.html. Accessed 13 March 2020.

Pratt, William. Singing the Chaos: Madness and Wisdom in Modern Poetry. Columbia, Missouri: University of Missouri Press, 1996.

Read, Sir Herbert, et al., editors. The Collected Works of C.G.Jung. Translated by R.F.C.Hull, London: Routledge and Kegan Paul, 1953-1978.

Rees, R. I. English literature: An introduction for foreign readers. London: the McMillan press, Ltd., 1984.

Rezaei, Somaye. "Manoochehr Ashtiani: Heidegger is a mystic, not a philosopher." Tehran Times, Nov. 15, 2017, pp. 12-26. https://www.tehrantimes.com/news/418520/Manoochehr-Ashtianiheidegger-is-a-mystic-not-a-philosopher. Accessed 3 Sept. 2020.

Ross, David A. Critical Companion to William Butler Yeats: A Literary Reference to His Life and Work. New York: Infobase Publishing, 2009.

Sahih al-Bukhari. "To make the Heart Tender" (Ar-Riqaq) - كتاب الرقاق, Hadith 6502. https://sunnah.com/bukhari:6502. Accessed 5 Sept. 2020.

Sarker, Sunil Kumar. W.B. Yeats Poetry and Plays. New Delhi: Atlantic Publishers \& Dist, 2002.

Schmidt, Martin. "Individuation and The Self." The Society of Analytical Psychology: Jungian Analysis and Psychotherapy. https://www.thesap.org.uk/resources/articles-on-jungian-psychology2/about-analysis-and-therapy/individuation/. Accessed 20 Sept. 2020.

Tülüce, Mustafa Uğur. William Butler Yeats And Mysticism: A Neo-Platonic Approach To His Poetry. M.A. Thesis, The Graduate School of Social Sciences of Middle East Technical University, Sept. 2017, 103 pages. http://etd.lib.metu.edu.tr/upload/12621546/index.pdf._Accessed 9 March 2020.

Ullah, Sahar I. Medieval Arabic-Islamic Poetics: The Transformation of the Amatory Prelude. Ph.D. Dissertation, School of Arts and Sciences, Columbia

(Symbols of Mystical Ecstasy and Divine Love...) Dr. Gehan Deeb 
University, 2018. https://academiccommons.columbia.edu/doi/10.7916/ D82236CW/download. Accessed 13 Feb. 2020.

Uždavinys, Algis. The Heart of Plotinus: The Essential Eneads Including Porphyry's On the Cave of the Nymphs. World Wisdom, Inc, 2009. https://books.google.com/books?id=jJFmcaczHSoC. Accessed 23 Feb. 2020.

Vaughan-Lee, Llewellyn. "Anima Mundi: Awakening the Soul of the World." Sufi Journal, The Golden Sufi Center, Sept. 2005. Anima Mundi: Awakening the Soul of the World I The Golden Sufi Center. Accessed 10 Feb. 2020.

White, Alana. "Symbolism in the Poetry of William Butler Yeats." Masters Theses and Specialist Projects, 1972, paper 1035. http://digitalcommons.wku.edu/theses/1035. Accessed 14 Jan. 2020.

Yeats, W. B. A Vision (1925). London: The Macmillan Press, 1974.

Yeats, W. B. The Collected Poems of W. B. Yeats. United Kingdom: Wordsworth Editions Ltd, 2000.

Young, Julian. Heidegger's Philosophy of Art. Cambridge: Cambridge University Press, 2001.

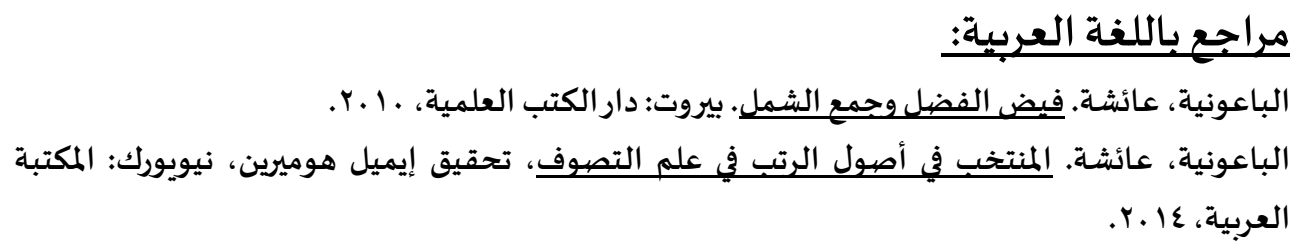

Homerin-Principles-of-Sufism-Arabic-only-corrected-version.pdf

(libraryofarabicliterature.org)

$$
\text { الربابعة، حسن محمد. عائشة الباعونية شاعرة ، إربد : دار الهلال، 199V. }
$$

